INFRARED SURVEYS, RADIANT FLUX, AND TOTAL HEAT DISCHARGE AT MOUNT BAKER VOLCANO, WASHINGTON, BETWEEN 1970 AND 1975

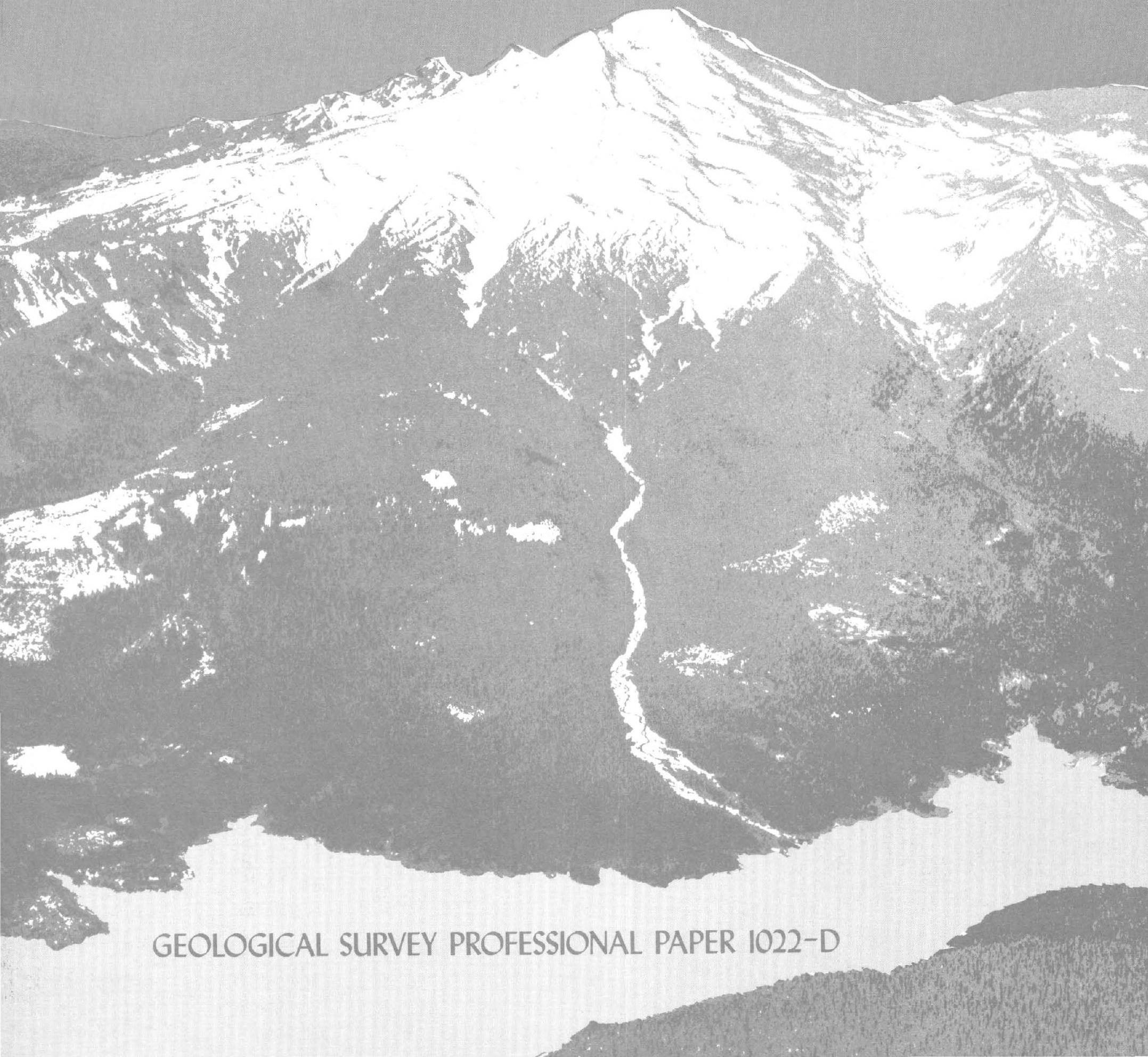



INFRARED SURVEYS, RADIANT FLUX, AND TOTAL HEAT DISCHARGE AT MOUNT BAKER VOLCANO, WASHINGTON,

BETWEEN 1970 AND 1975 


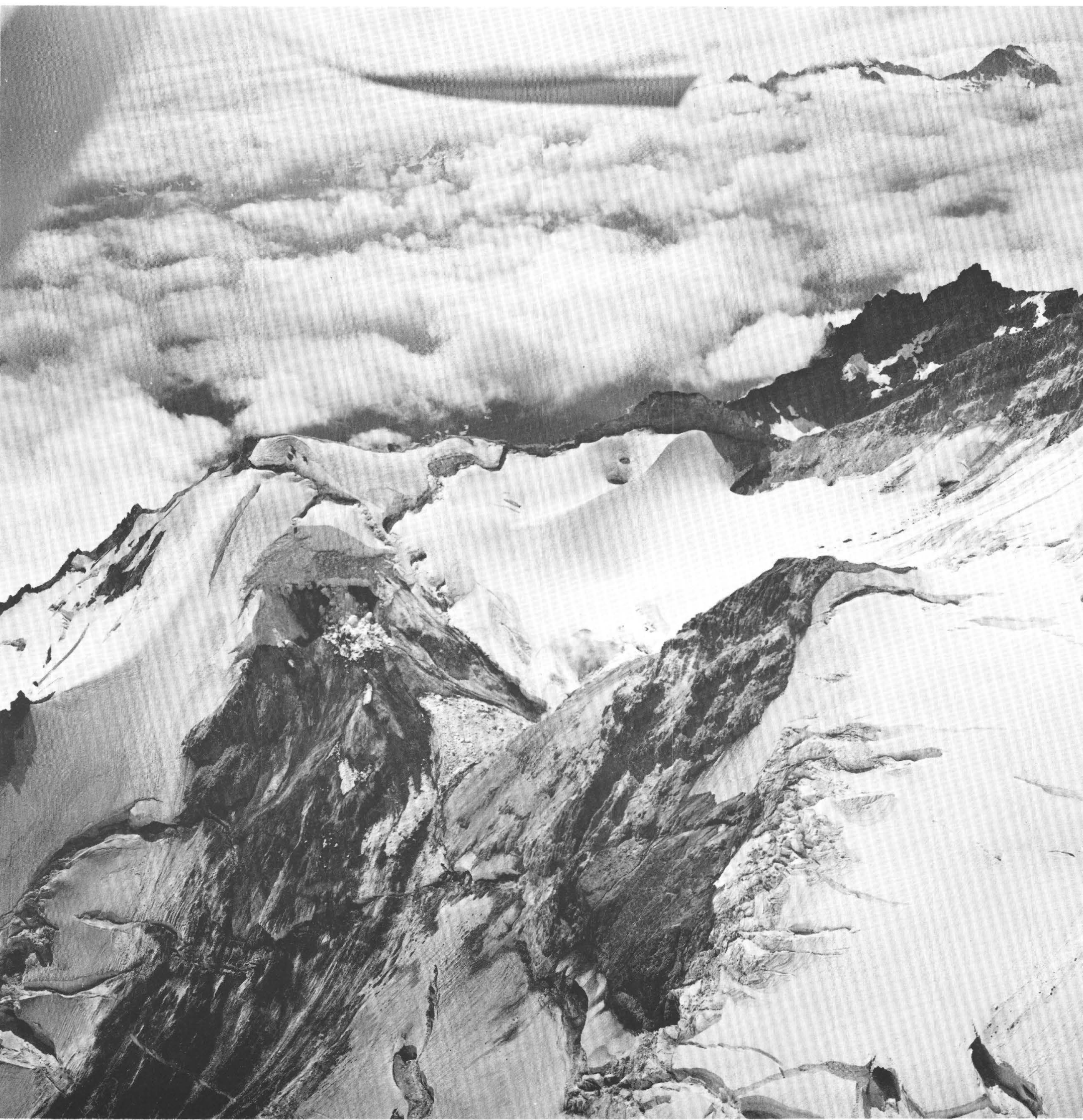

FrontisPiece-Mount Baker's Sherman Crater in August 1969, as viewed from the east. Photograph K692-4 by Austin Post, August 2, 1969. 


\section{Infrared Surveys, Radiant Flux, and Total Heat Discharge at Mount Baker Volcano, Washington, Between 1970 and 1975}

By JULES D. FRIEDMAN and DAVID FRANK

VOLCANIC ACTIVITY AT MOUNT BAKER, WASHINGTON

GEOLOGICAL SURVEY PROFESSIONAL PAPER $1022-D$

A comparison of 1970-1973 and 1975 thermal activity

using aerial infrared surveys, ground temperatures

relayed via satellite, and a two-point differential

geothermal-flux model based on heat balance

of the ground surface

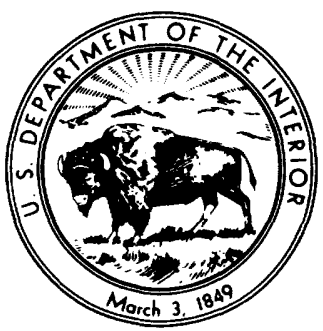

UNITED STATES GOVERNMENT PRINTING OFFICE, WASHINGTON：1980 


\section{UNITED STATES DEPARTMENT OF THE INTERIOR}

CECIL D. ANDRUS, Secretary

\section{GEOLOGICAL SURVEY}

H. William Menard, Director

\section{Library of Congress Cataloging in Publication Data}

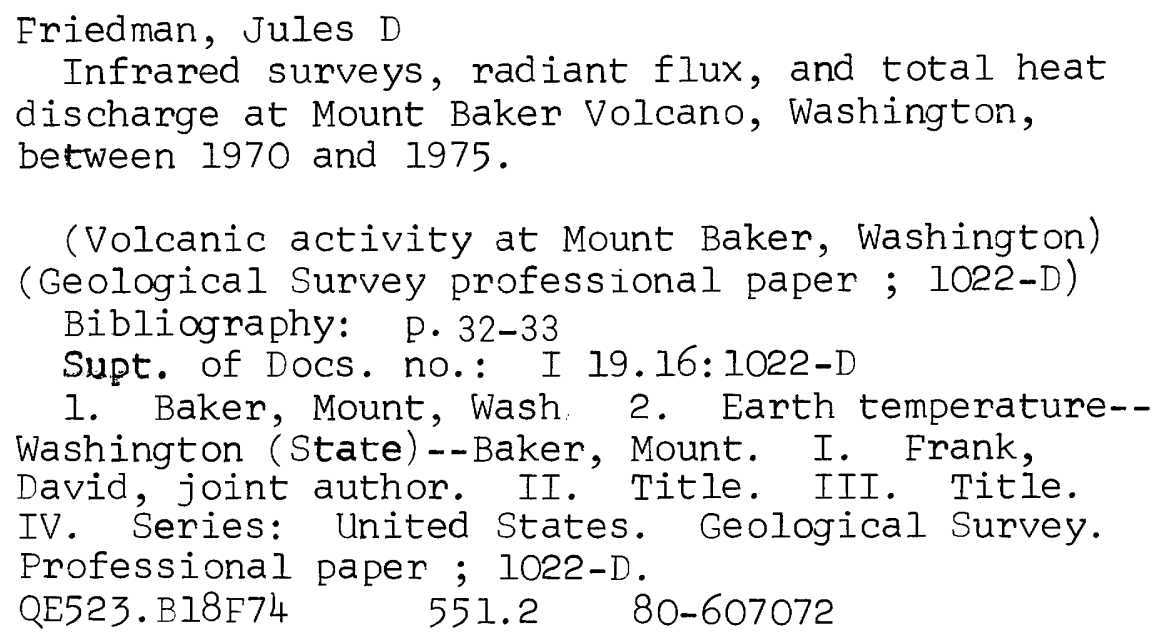

For sale by the Superintendent of Documents, U.S. Government Printing Office Washington, D.C. 20402 


\section{CONTENTS}

Abbreviations

Terminology and conversion factors

Abstract

Introduction

Acknowledgments

Geologic setting of Mount Baker

Quaternary eruptions

Historic activity

Fumarolic activity between 1970 and 1974

Sherman Crater fumarole field

Dorr Fumarole Field

Increase in fumarolic activity in 1975

Surveillance and mapping by aerial infrared scanner

Geologic interpretation of infrared images .............

Radiant-flux estimation

Corrections for absorption and emission by atmospheric water vapor, carbon dioxide, and aerosols --

Temperature corrections for surface emissivity -....-

Thermographic survey of November 20, 1972

Electronic thermal-sensor array and Landsat data collection

platform

Heat-flux estimates _...............

Differential geothermal flux from Dorr Fumarole Field, 1972

\begin{tabular}{r|r}
\hline & \\
Page \\
VI \\
VII \\
D1 \\
1 \\
2 \\
2 \\
4 \\
4 \\
8 \\
8 \\
8 \\
8 \\
8 \\
8 \\
10 \\
\\
14 \\
14 \\
16 \\
18 \\
18 \\
\hline
\end{tabular}

Heat-flux estimates-Continued Page Differential geothermal flux from Sherman Crater, 1972 and $1975 \ldots . . . . . . .23$

Heat loss from central pit lake, $1975 \ldots \ldots$

Evaporation _....... 24

Conduction and diffusion to atmosphere _-___- 25

Radiant heat loss

Total heat loss _................ 26

Differential geothermal flux and comparison of

heat-loss estimates .............. 26

Heat exchange via mass transfer from fumaroles,

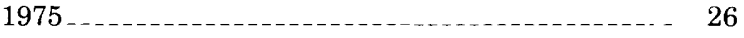

Advective heat loss via melt-water drainage, 1972 and 1976 . 26

Analysis of propagation of error in flux calculations_- 26

Heat-flux summary

Inferred energy yield during repose $\ldots \ldots \ldots$

Comparison between 1972 energy yield and 1975 energy yield

Discussion _...

Summary and conclusions

References cited _._. 32

\section{ILLUSTRATIONS}

FrontisPieCE. Photograph of Mount Baker's Sherman Crater, August 1969.

2. Landsat 1 image showing the regional setting of Mount Baker

3-6. Photographs of Mount Baker:

3. East facade in September 1962, showing Sherman Crater, summit dome, and Sherman Peak

4. Southwest facade in September 1962

5. Sherman Crater

6. Vertical view of Dorr Fumarole Field on the north slope of Mount Baker, June 1975

7. Schematic diagram of RS-14 aerial infrared scanner

8. Infrared images of Sherman Crater, April 1971 to April 1973

9. Vertical view of Sherman Crater, September 1963

10. Enlarged infrared image of November 1972

11. Planimetrically corrected distribution of anomalously warm areas of Sherman Crater and Dorr Fumarole Field ..

12. Isodensity scan of infrared image of November 1972

13. Infrared image of Sherman Crater, August 1975

14. Differential radiant exitance as a function of ground kinetic temperature at Mount Baker. November 1972

15. Kinetic temperatures at Dorr Fumarole Field, February 8 through March 17, 1973

16. Evaporative heat loss from the central pit lake, Sherman Crater 
1. Thermographic surveys over Mount Baker, Wash., before 1975

2. Differential radiant flux and nonadvective heat flux at Dorr Fumarole Field and Sherman Crater, Mount Baker, Wash

3. Thermal sensor array for Data Collection Platform 6251, Dorr Fumarole Field, Mount Baker, Wash

4. Anomalous nonadvective heat flux from Sherman Crater in 1972 and 1975

5. Estimated total heat discharge from Sherman Crater, Mount Baker, Wash., 1972 and 1975

6. Estimated mean deviation in independent variables in flux calculations

7. Analysis of propagation of error in flux calculations

8. Comparative energy yield of selected volcanoes and geothermal areas

a

B.P.

${ }^{\circ} \mathrm{C}$

$\mathrm{c}_{\mathrm{p}}$

cal

cm

D

$\mathrm{D}_{0}$

DCP

$\Delta \mathrm{G}$

$\mathbf{e}_{\mathrm{a}}$

$\mathbf{e}_{\mathrm{s}}$

$\mathbf{e}_{\mathrm{w}}$

$\mathrm{F}_{\mathrm{ad}}$

$\mathrm{F}_{\mathrm{b}}$

$\mathrm{F}_{\mathrm{e}}$

$F_{\mathrm{h}}$

$\mathbf{F}_{\mathrm{s}}$

f

g

$\mathrm{H}$

hfu

hr

ir

J

K

kg

$\mathrm{km}$

$\mathrm{kPa}$

$\lambda$

M

MW

m

$m$

m m.s.l.

$\operatorname{mrad}$

$\mu \mathrm{m}$

\section{ABBREVIATIONS}

$=$ half-scan angle of infrared scanner

$=$ years before present

$=$ degree Celsius

$=$ specific heat of air at constant pressure

= calorie

$=$ centimeter

$=$ coefficient of diffusion of water vapor into air (transfer velocity)

$=$ value of $\mathrm{D}$ at $273 \mathrm{~K}(=0.22)$

$=$ data collection platform

$=$ differential geothermal flux

$=P_{d}$

$=\mathrm{P}_{\mathrm{s}}$

$=$ vapor pressure

$=$ effective surface emissivity

$=$ advective heat loss by icemelt, stream runoff, and mass transfer to atmosphere from fumarole emanations

$=$ differential radiant flux

$=$ heat lost to the atmosphere by evaporation

$=$ net outgoing flux from a water surface via eddy diffusion and molecular conduction

$=$ total nonadvective heat loss

$=$ relative humidity of fumarole vapor $(=0.95)$

$=$ gram

$=$ convective heat flow

$=$ enthalpy of saturated water vapor $(=630.4 \mathrm{cal}$ $\mathrm{g}^{-1}$ at $90^{\circ} \mathrm{C}$ and $3,000 \mathrm{~m} \mathrm{m.s.l.)}$

$=$ heat-flow units $\left(=10^{-6} \mathrm{cal} \mathrm{cm}^{-2} \mathrm{~s}^{-1}\right)$

$=$ hour

$=$ infrared

$=$ joule

$=$ kelvin

$=$ kilogram

$=$ kilometer

$=$ kilopascal

$=$ wavelength of radiation

$=$ rate of evaporation in $\mathrm{kg} \mathrm{m}^{-2} \mathrm{hr}^{-1}$

$=$ megawat

$=$ meter

$=$ cloudiness

$=$ meters above mean sea level

$=$ milliradian

$=$ micrometer

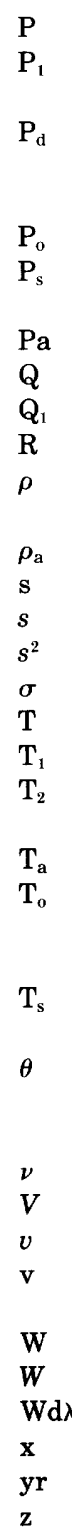

$=$ atmospheric pressure

$=$ atmospheric pressure in $\mathrm{mm}$ of $\mathrm{Hg}(=\mathbf{5 2 7 . 1 3}$ at $3000 \mathrm{~m}$ m.s.l.)

$=$ pressure of water vapor in atmosphere, in $\mathrm{mm}$ of $\mathrm{Hg}$ ( $=3.6632$ for Mount Baker on June 26, 1975)

$=1$ atmosphere pressure $(101.3 \mathrm{kPa})$

= saturated pressure of water vapor in $\mathrm{mm}$ of $\mathrm{Hg}\left(=39.898\right.$ at $\left.34^{\circ} \mathrm{C}\right)$

$=$ pascal

$=$ net geothermal flux

$=$ heat lost to atmosphere by mass transfer

$=$ Bowen ratio $\left(\mathrm{F}_{\mathrm{h}} / \mathrm{F}_{\mathrm{e}}\right)$

$=$ density of saturated water vapor at $90^{\circ} \mathrm{C}$ $\left(=0.428 \times 10^{-3} \mathrm{~g} \mathrm{~cm}^{-3}\right)$

$=$ air density in $\mathrm{g} \mathrm{cm}^{-3}$

$=$ seconds

$=$ probable error

$=$ variance

= Stefan-Boltzmann constant

$=$ temperature of air above lake surface, in $\mathrm{K}$

$=$ mean temperature of warm surface, in $\mathrm{K}$

$=$ mean temperature of cool reference surface $(=273 \mathrm{~K}$ in this report)

$=$ air temperature $\left({ }^{\circ} \mathrm{C}\right)$

= surface temperature of anomalously warm area, in $\mathrm{K}$ (in differential geothermal flux equation)

$=$ temperature of warm water surface $\left(=34^{\circ} \mathrm{C}\right.$ on June 11, 1975)

= surface temperature of anomalously warm area, in ${ }^{\circ} \mathrm{C}$ (in differential geothermal flux equation)

$=$ ground temperature

$=\mathrm{P}_{\mathrm{s}}$

$=P_{\mathrm{d}}$

$=$ volumetric rate of transfer of fumarole vapor $\left(=0.35 \mathrm{~m}^{3} \mathrm{~s}^{-1}\right.$ for 1 percent of fumaroles)

$=$ watts

$=$ wind speed in $\mathrm{m} \mathrm{s}^{-1}$

$=$ differential radiant exitance $\left(=\sim F_{b}\right)$

$=$ vertical pathlength of scanner

$=$ year

$=$ average transmission pathlength of scanner 


\section{TERMINOLOGY}

[For additional terms see Frank and others, 1977, p. VII.]

Advective heat loss. Heat transfer from the ground surface by the horizontal movement of water or air.

Aerial infrared scanner. An airborne line-scan system that produces a thermal image, usually in the $8-14 \mu \mathrm{m}$ region.

Bowen ratio. The ratio of convective to evaporative heat transfer. Differential geothermal flux. A measure of the change in geothermal flux relative to that of a standard surface.

Differential radiant exitance (flux). A measure of the change in power radiated per unit area, relative to that of a standard surface.

Emissivity. A measure of the radiant efficiency of a body compared to that of a perfect radiator (blackbody).

Enthalpy. A thermodynamic quantity defined as the sum of a body's internal energy plus the product of its volume and pressure. Synonymous with heat content.

Image density. A measure of the transparency or emulsion density of an exposed, processed film or photographic plate.

Infrared image. An image produced outside the wavelength range of photographic sensitivity (which is generally less than $1 \mu \mathrm{m}$ ) in the infrared, using line- or raster-scan systems, typically airborne.

Infrared survey. An aerial survey technique in which a line-scan system collects thermal infrared radiation to produce twodimensional images of the scene. The infrared images produced are sually of the Earth's surface.

Kinetic temperature. The temperature measured by direct contact with a body.

Landsat. The Landsat 1 satellite system, launched July 3, 1972, by the U.S. National Aeronautics and Space Administration (NASA) as ERTS-1, was stabilized in a near-polar, sun-synchronous orbit approximately $907 \mathrm{~km}$ above the Earth. The satellite contains two imaging systems, the Multispectral Scanner, a 4-band scanner operating in the solar-reflected spectral regions from 0.5 to $1.1 \mu \mathrm{m}$ wavelength, and the Return Beam Vidicon, which also records reflected visible and near-infrared radiation. A third system, the Data Collection System, receives and relays data from Earth-based monitoring instruments.

Landsat data collection platform. A ground-based formatting and transmitting unit coupled to an instrument station, such as a thermistor array; a component of the Landsat Data Collection System (DCS), which collects, transmits, and disseminates data from remotely located Earth-based sensors. The system includes remote data collection platforms (DCP's), satellite relay equipment, ground receiving site equipment, and a ground data handling system.

Landsat image. A line-scan image of the Earth's surface recorded in several spectral bands simultaneously through the same system, namely, the Multispectral Scanner System (MSS) of Landsat 1.

Moist adiabatic lapse rate. A measure of the decrease in temperature of saturated air ascending in the atmosphere. Synonymous with the pseudo-adiabatic lapse rate.

Radiometric temperature. The radiation temperature as measured by a radiometer or infrared scanner.

Radiosonde. An instrument which, when transported through the atmosphere, measures pressure, temperature, and humidity and transmits these readings to a base station.

Stefan-Boltzmann constant. The Stefan-Boltzmann constant, $\sigma$, occurs in the relationship $\mathrm{R}_{\mathrm{BB}}=\sigma \mathrm{T}^{4}$, which relates radiant power to absolute temperature; $\sigma$ has the value $5.679 \times 10^{-8} \mathrm{~W} \mathrm{~m}^{-2}$.

Synoptic. Relating to or displaying general atmospheric, weather, and terrain conditions as they exist simultaneously over a broad area.

Thermographic image. Synonymous with thermal image.

Transfer velocity. The coefficient for rate of diffusion of water vapor in the air.

\section{CONVERSION FACTORS}

For units of length, area, and volume

\section{Multiply}

$\mathrm{ft}$ (feet)

mi (miles)

$\mathrm{ft}^{3}$ (cubic feet)

$\mathrm{mi}^{2}$ (square miles)

Multiply

cal (gram-calorie)

J (joule $=W-$ sec)

Multiply

$1 \mathrm{cal} \mathrm{s}^{-1} \mathrm{~cm}^{-2}$

$1 \mathrm{cal} \mathrm{s}^{-1} \mathrm{~cm}^{-2}$

$1 \mathrm{~W} \mathrm{~m}^{-2}$

$1 \mathrm{erg} \mathrm{s}^{-1} \mathrm{~cm}^{-2}$

$1 \mathrm{erg} \mathrm{s}^{-1} \mathrm{~cm}^{-2}$
By

$3.048 \times 10^{-1}$
1.609
$2.832 \times 10^{-2}$
2.590

For energy units

By

4.187

$10^{7}$

For energy flux

$$
\text { By }
$$

$4.187 \times 10^{4}$

$4.187 \times 10^{7}$

$2.388 \times 10^{-5}$

$10^{-3}$

$2.388 \times 10^{-8}$
To obtain

m (meters)

km (kilometers)

$\mathrm{m}^{3}$ (cubic meters)

$\mathrm{km}^{2}$ (square kilometers)
To obtain

$J$ (joule) erg (dyne-cm)
$\mathrm{W} \mathrm{m}^{-2}$

erg $\mathrm{s}^{-1} \mathrm{~cm}^{-2}$

cal s $\mathrm{s}^{-1} \mathrm{~cm}^{-2}$

$\mathrm{W} \mathrm{\textrm {m } ^ { - 2 }}$

cal s $\mathrm{s}^{-1} \mathrm{~cm}^{-2}$ 



\title{
INFRARED SURVEYS, RADIANT FLUX, AND TOTAL HEAT DISCHARGE AT MOUNT BAKER VOLCANO, WASHINGTON, BETWEEN 1970 AND 1975
}

\author{
By Jules D. Friedman and David Frank
}

\begin{abstract}
Reconstruction of the 1972 surface thermal regime at Sherman Crater and the Dorr Fumarole Field of Mount Baker, based on seven aerial infrared surveys (1970-73) and on thermistor measurements relayed through a Landsat data collection platform, permits an assessment of Mount Baker's heat exchange with the atmosphere before thermal emission increased in 1975. Calibrated infrared images obtained in November 1972, contoured for apparent radiometric temperature and corrected for atmospheric attenuation and surface emissivity, indicate a differential radiant-flux value of $1.0 \pm 0.6$ megawatt for Sherman Crater. Total heat discharge from the crater was estimated at $11 \pm 6$ megawatts, which includes less than 8 megawatts from fumarolic emission and advective loss. Several methods were used in combination to produce this estimate, including a modified two-point differential geothermal-flux model based on the heat balance of the ground surface and on surface and air temperatures (the model was adapted for use with infrared-scanner output). Similar calculations applied to infrared images and field data for 1975 yield a differential radiant flux of $3 \pm 1.7$ megawatts and a total heat discharge of $80 \pm 44$ megawatts, including advective losses of about 28 megawatts from ice melt and melt-water drainage and direct losses of $38 \pm 38$ megawatts from fumaroles and vapor plumes. Heat loss by radiation represented 9 percent of the total discharge in 1972 and 4 percent in 1975 . The Bowen ratio, $R$, linking heat loss by conduction and turbulence to that by evaporation was 0.3 . The estimated net energy yield in 1975 exceeded that in 1972 by $2.1 \times 10^{15}$ joules per year.
\end{abstract}

\section{INTRODUGTION}

On March 10, 1975, Mount Baker's state of repose was interrupted by a sizable thermal event, the magnitude, duration, and cause of which are the subject of continuing investigation. This report summarizes the results of thermal investigations, including aerial infrared surveys, undertaken at Mount Baker by the U.S. Geological Survey between 1970 and 1974, prior to the distinct change in pattern of activity that occurred on March 10,1975, and before the current series of investigations was started. Changes at Mount Baker attendant upon the 1975 thermal event have been reported by Malone and Frank (1975), Easterbrook
(1975), Rosenfeld (1976), Eichelberger and others (1976), Frank and Post (1976), McLane, Finkelman, and Larson (1976a, b), Fretwell (1976), Kiver and Steele (1976), Nitsan (1976), Sato and others (1976), Malone (1976a, b, 1979), Nolf (1976), Frank, Meier, and Swanson (1977), Radke, Hobbs, and Stith (1976), and Bortleson, Wilson, and Foxworthy (1977).

Frank, Meier, and Swanson (1977, p. 1) made estimates of that part of the heat flux at Sherman Crater that would account for the observed snow and ice loss. They found that this component of the total heat flux increased by roughly one order of magnitude from about $2 \mathrm{MW}$ at $10^{\circ} \mathrm{W} \mathrm{m}^{-2}$ before 1975 , to about $30 \mathrm{MW}$ at $180 \mathrm{~W} \mathrm{~m}^{-2}$ during 1975 . One object of the present investigation is to expand these estimates to encompass a wider range of heat-transfer mechanisms in order to approximate the total thermal energy output from Mount Baker before and during 1975. To accomplish this, the magnitude of heat transfer via radiation, conduction, diffusion, and evaporation from anomalously warm, ice-free ground within Sherman Crater is estimated by workup of aerial-infraredsurvey and ground-temperature data; mass transfer to the atmosphere from fumaroles and other advective heat losses are also estimated.

Because of the masking effect of geologic, hydrologic, and topoographic variations (Banwell, 1970, p. 45-48; Watson, 1975 , p. 131), heat-flow levels recordable by infrared scanner are not equivalent to the minimum detectable geothermal flux. Depending on the time of day surveys are made, the mean diurnal surface temperature, and the level of error in estimating thermophysical properties of the ground surface, the heatflux equivalent of absolute-temperature error may be as much as several thousand heat-flow units (Watson, 1975 , p. 131). However, estimates of the differential radiant flux can be made with reasonable accuracy in relation to an established ground-temperature reference level. 
In the present investigations of Mount Baker, aerial infrared images provide planimetric data on the configuration and size of areas at the surface at incremental, radiometric-temperature levels. Where the thermophysical properties and temperature regime of the surface materials are known, the differential radiant flux is estimated from the aerial infrared data by application of the Stefan-Boltzmann function and a twopoint method which derives the radiant flux in relation to $273-\mathrm{K}$ surfaces. Based on the concept of heat balance of the ground surface, several models for estimating components of the overall heat-flux density from surface-temperature data are compared: namely, the two-point model proposed by Sekioka and Yuhara (1974); the semi-empirical model of Dawson (1964) for convection-dominated systems, built upon the work of Ångström (1920, 1925), Bowen (1926), Brunt (1939), and Sutton (1953); and the model of Robson and Willmore (1955) for heat lost from warm lake surfaces, based on evaporation-pan theory.

The total energy yield from Sherman Crater for the 1972 period is then compared with that following the increased fumarolic activity of 1975 to assess the magnitude of the increase. Possible geologic causes of the increased thermal activity are discussed briefly.

\section{ACKNOWLEDGMENTS}

The thermal investigations of Mount Baker in 1972 and 1973 reported herein were funded by the U.S. National Aeronautics and Space Administration and the U.S. Geological Survey as part of Landsat 1 experiment SR 251. Six aerial infrared surveys of Mount Baker were carried out for the Geological Survey by the U.S. Forest Service, and one was conducted by the National Aeronautics and Space Administration. In addition, Charles L. Rosenfeld, Oregon State University, kindly provided 1975 and 1976 aerial infrared images of Mount Baker and gave permission for their publication in this report. The helicopter group of the 92d Aviation Company, U.S. Army, Paine Field, Everett, Wash., provided helicopter support for installation of Data Collection Platform (DCP) 6251. The authors acknowledge with thanks the assistance of S. M. Hodge, R. M. Krimmel, and Austin Post in installation and removal of DCP 6251.

Analysis of models for geothermal flux estimation from surface manifestations, as applied in the present report, was carried out by the senior author in 1975 and 1976 with funding support of the U.S. Geological Survey geothermal program. David V. Fitterman kindly prepared an analysis of the propagation of error in the flux calculations.

\section{GEOLOGIC SETTING OF MOUNT BAKER}

Mount Baker $\left(48^{\circ} 47^{\prime}\right.$ N., $121^{\circ} 49^{\prime}$ W. $)$ is the most northerly of a north-south chain of Quaternary volcanoes of the Cascade Range in Washington (fig. 1). It consists of porphyritic andesitic lava flows and breccia that form a glacier-covered composite cone built upon a complex of older rocks (Coombs, 1939; Misch, 1966). The summit is $3,285 \mathrm{~m}$ above mean sea level and about $3,000 \mathrm{~m}$ above the Skagit River valley, which lies 26 $\mathrm{km}$ to the south (fig. 2).

The present cone (figs. 3,4 ) was formed before the last major glaciation 25,000 to 10,000 years ago and may be considerably older (Hyde and Crandell, 1975, p. 1). It abuts extrusive rocks of the Black Buttes, an earlier eruptive center (Coombs, 1939, p. 1500). All of the higher lava flows on the cone appear to dip away from a source area near a broad summit ice dome. On the 1952 topographic map (U.S. Geol. Survey, Mount Baker quadrangle, $1: 62,500$ ), a prominent crater is centered $800 \mathrm{~m}$ to the south and $300 \mathrm{~m}$ lower in altitude than the ice dome and is termed Summit Crater. This crater (figs. 5, 9), partly filled with snow and ice (crater glacier) which descends from the actual summit to the north, is now called Sherman Crater (Frank and others, 1975, p. 77). Sherman Peak is a segment of the

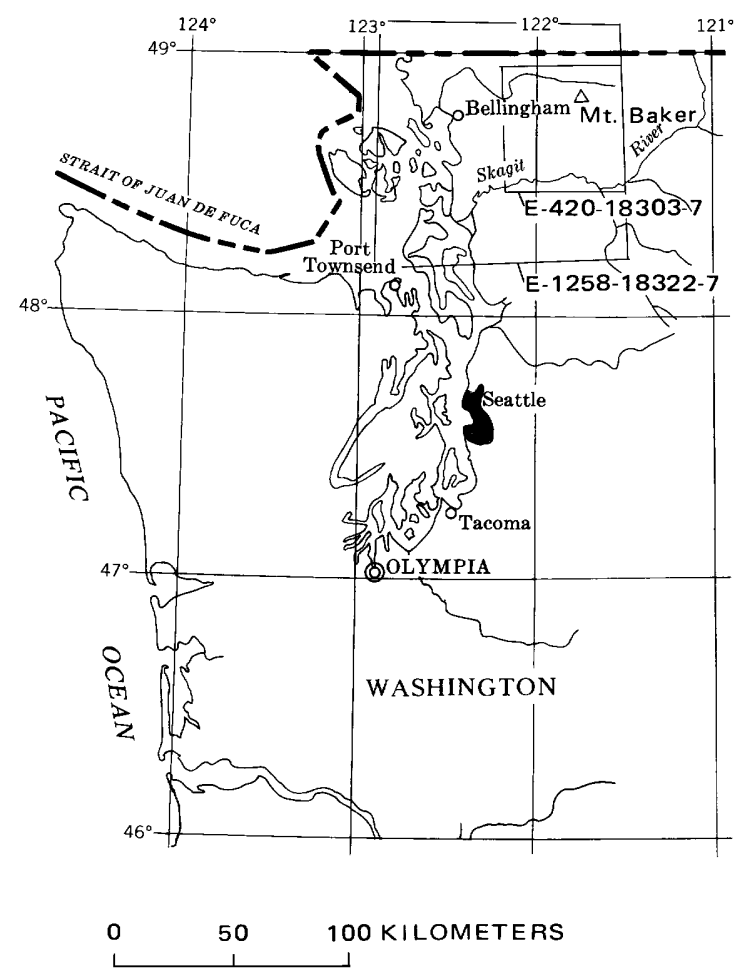

Figure 1.- Index map of Mount Baker and the area covered by portions of Landsat images $\mathrm{E}-$ 1258-18322-7 (fig. 2) and E-420-18303-7 (fig. 3). 


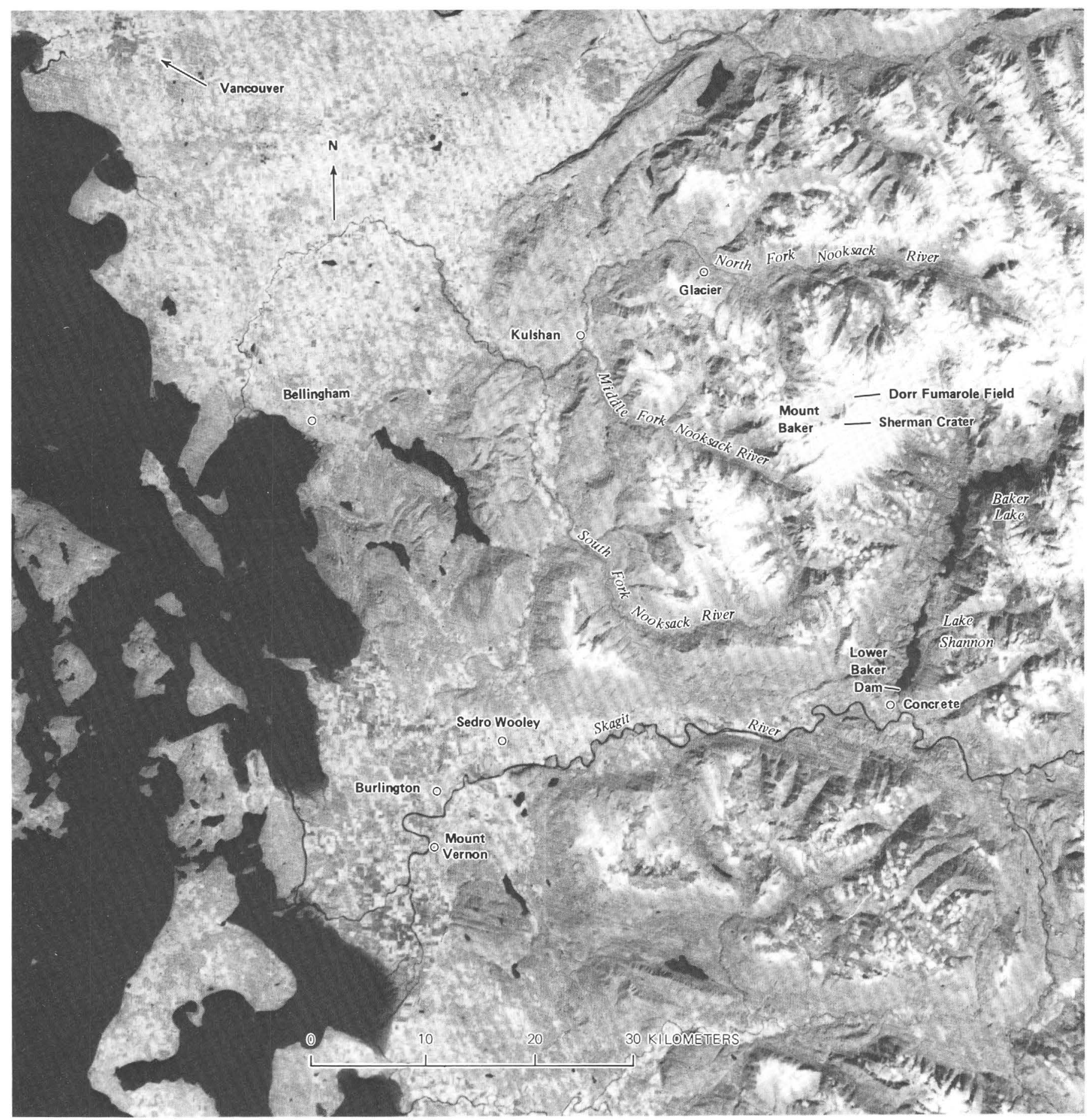

Figure 2.-A portion of Landsat image E-1258-18322- 7 taken April 7, 1973. This image shows the regional setting of Mount Baker, with Baker Lake and Lake Shannon reservoirs to the east, the South Fork Nooksack and Skagit River valleys to the south, and the Middle Fork and North Fork Nooksack River valleys to the west and north. Intensive cultivation is discernible on the flood plains of the Skagit, Nooksack, and Fraser Rivers, to the southwest and northwest, respectively. Major population centers visible from north to south are part of the Vancouver, B.C., Canada, area, and Bellingham and Mount Vernon, Wash. The image shows regional snow conditions at about the time of the aerial infrared survey of April 29, 1973.

crater rim on the south side, and Lahar Lookout is a remnant of the rim on the east side, just north of a breach in the east crater rim. Other eruptive centers include the deeply eroded Black Buttes (fig. 4) and a small cinder cone at Schriebers Meadow near the south base of Mount Baker (Hyde and Crandell, 1975, p. 3). 


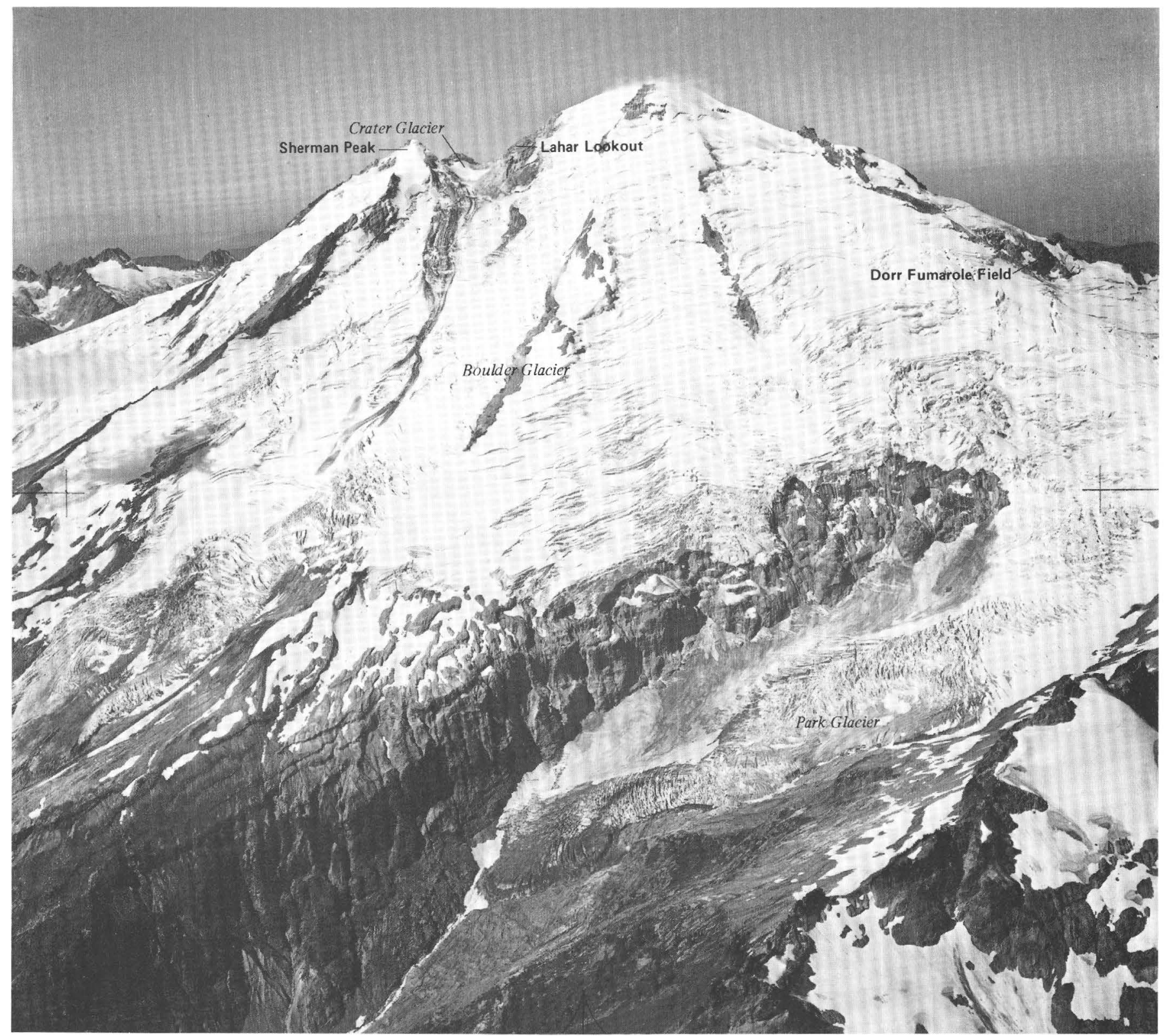

FigURE 3.-Mount Baker, as seen looking west, September 7, 1962. Sherman Crater is to the left of the summit dome (elevation 3,316 m). Sherman Peak is the secondary peak on the south rim of the crater. The crater glacier is visible through the east breach in the crater rim; above the east breach on the right is Lahar Lookout. Debris-avalanche scars and deposits extend from the east-rim area down the surface of Boulder Glacier. In the foreground is Park Glacier; to the right of the head of Park Glacier on the north slope is the Dorr Fumarole Field. Photograph R1-62-47 by Austin Post.

\section{QUATERNARY ERUPTIONS}

An early phase of eruptive activity in the Mount Baker area was K/Ar-dated by Easterbrook and Rahm $(1970$, p. 20$)$ at $400,000 \pm 200,000$ yrs B.P. The products of Holocene volcanic activity were studied by Hyde and Crandell (1975), who found evidence near Mount Baker of four tephra eruptions, three lava eruptions, and one period of pyroclastic flows, as well as many mudflows, within the last 10,000 years. Hyde and
Crandell (1975, p. 7) obtained a radiocarbon date of 390 \pm 200 yrs B.P. for a mudflow beneath the most recent tephra layer, which is thus no more than a few hundred years old and may have been erupted during historic time.

\section{HISTORIC ACTIVITY}

The first recorded eruption of Mount Baker since the beginning of settlement of the Oregon Territory oc- 


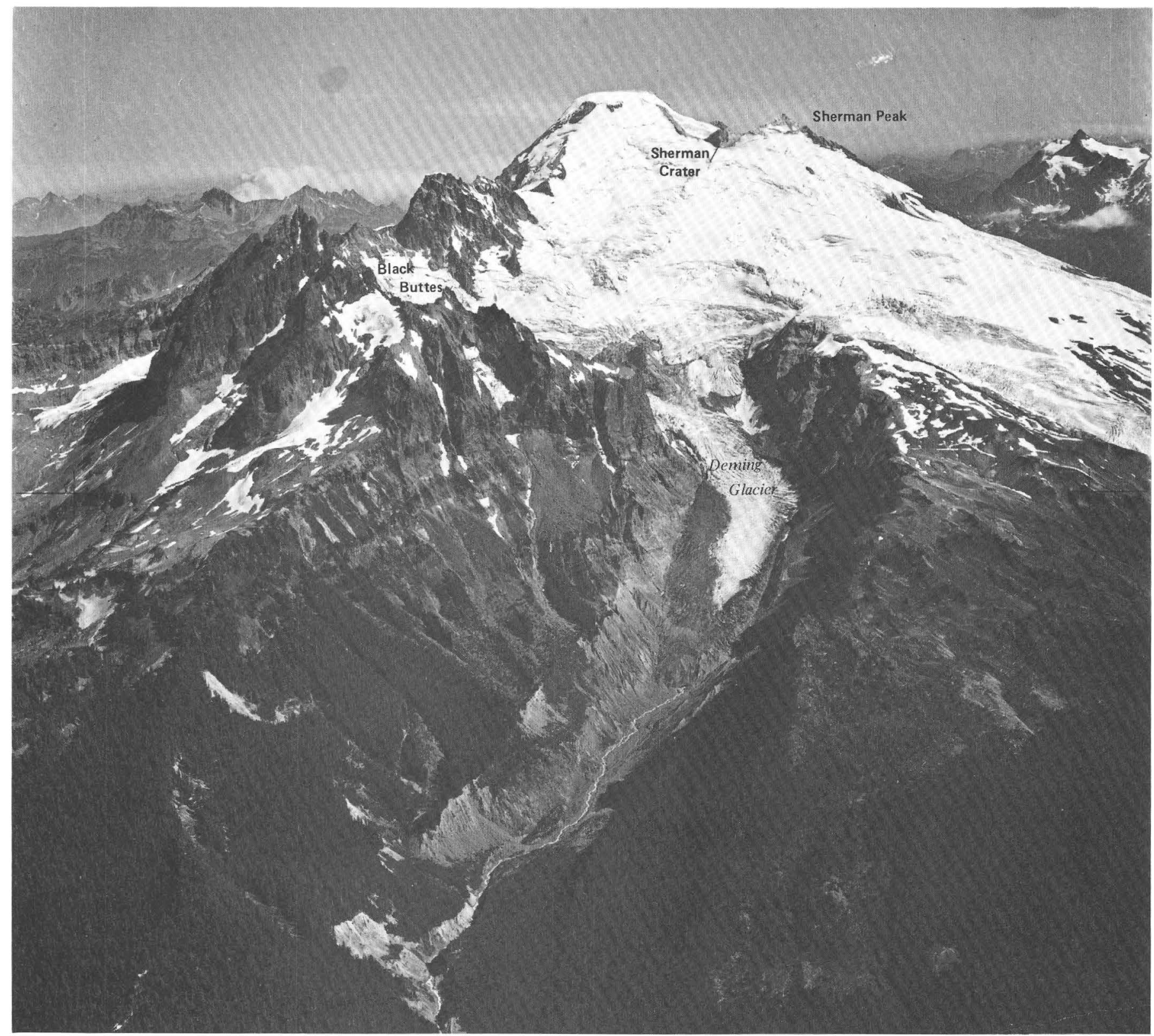

FIGURE 4.-Mount Baker, as seen looking northeast, September 7, 1962. Immediately to the right of and below the summit dome are the west-rim sector of Sherman Crater and Sherman Peak. The deeply eroded Black Buttes are to the left, and the valley of Deming Glacier is in the foreground. Photograph R1-62-34 by Austin Post.

curred in 1843 (Gibbs, 1874, p. 357-358), when a tephrafall was reported. Davidson (1885) was probably the first scientist to recognize and describe Sherman Crater as the site of eruptive activity at Mount Baker in the 1850 's. A short account by Tennant (reported in Pioneer-Democrat, 1859) states that two "large and bright jects [sic] of flame were seen having the appearance as if issuing from separate fissures or openings" on Mount Baker in 1859. On the whole, the historical evidence is good for volcanic activity in 1843, 1854, 1858, and 1859. However, Davidson's (1885) re- port of "smoke" emission in 1870 suggests a thermal event similar to that of 1975 . The exact nature of the eruptions of the 1850's remains unresolved, but they almost surely included large steam emanations from Sherman Crater. A photograph of Sherman Crater taken in 1900 (Rusk, 1924, p. 309) shows water vapor rising from an ice pit in the crater glacier. There are many references to steam emanations during the 20 th century. Frank, Meier, and Swanson (1977, p. 2-8) present a detailed review of fumarolic activity in Sherman Crater up to the present. 


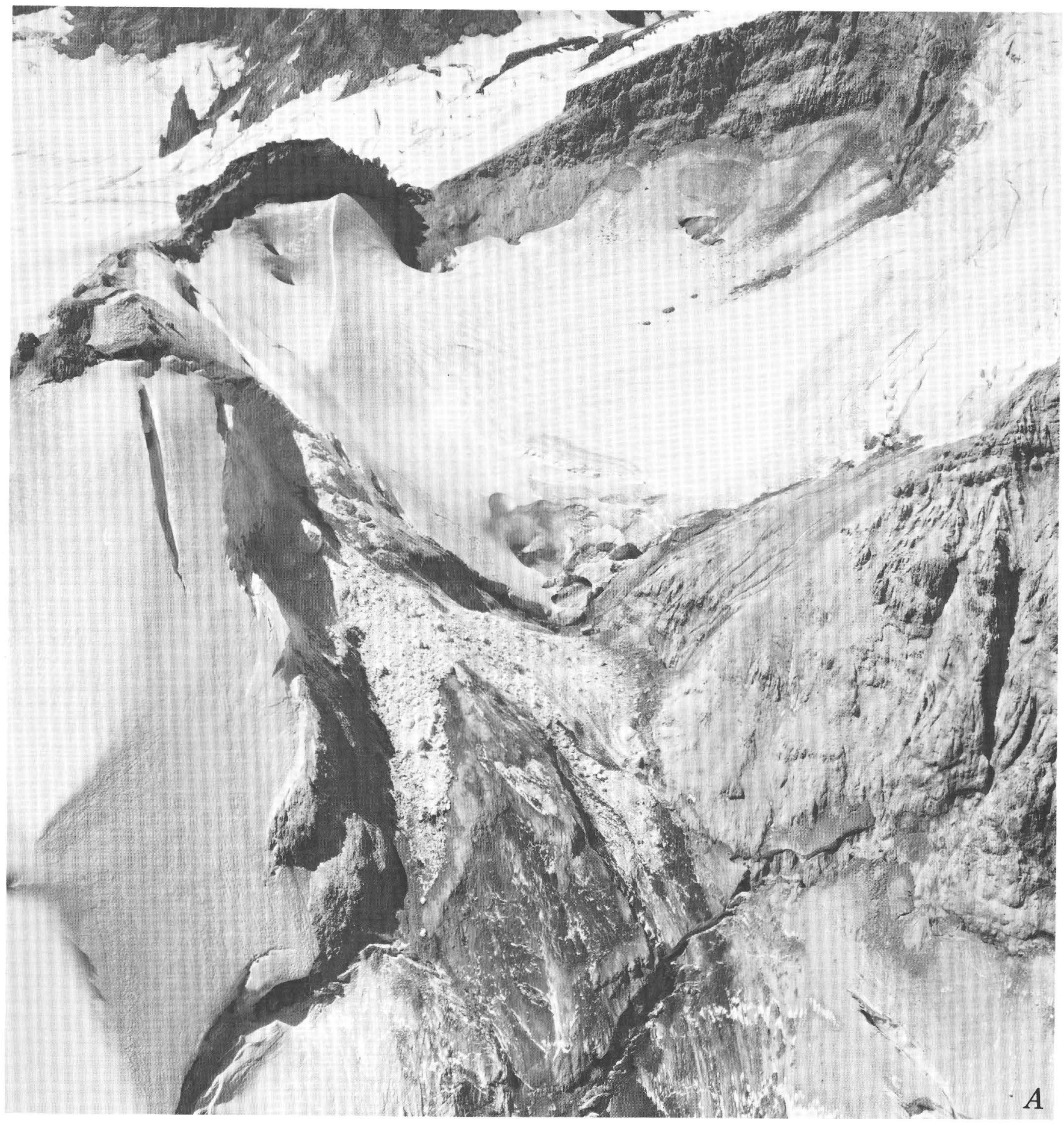

Figure 5. - Photographs of Sherman Crater. A, Oblique view looking west, August 22, 1969. The east breach and clusters of ice-perforation features are visible here. In the foreground are debris-avalanche scars on Sherman Peak and Boulder Glacier. Photograph 69 R1-20 by Austin Post. B, Ice pit in west-rim sector of crater glacier, July 2, 1972. Note figure in lower left (circled) for scale. Photomosaic by Dee Molenaar. 


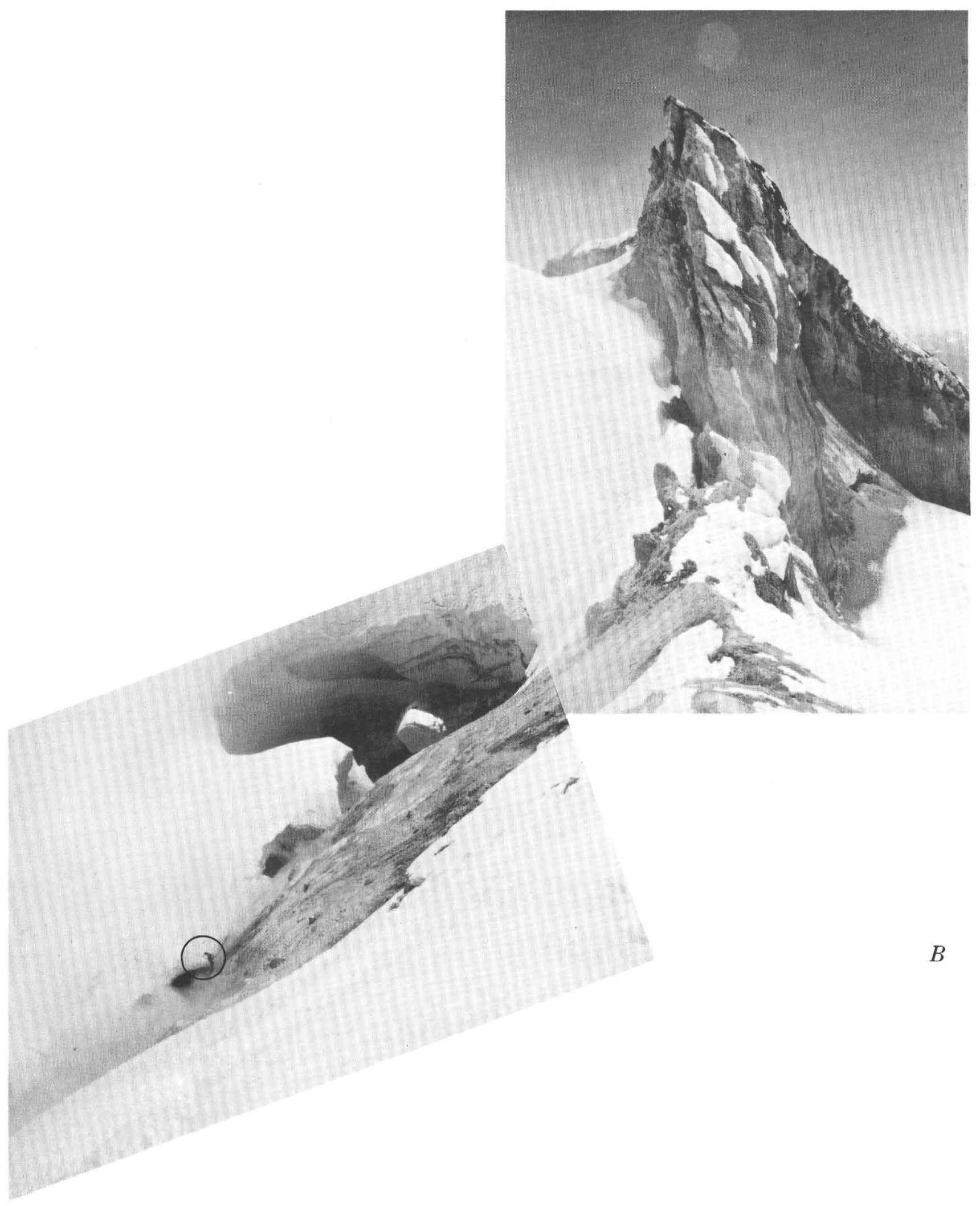

Figure 5.-Continued. 
Aerial photographs dating back to 1940 reveal the presence of ice perforations at fumaroles, and debris from geothermally induced avalanches from the south rim of Sherman Crater has been noted on Boulder Glacier every few years during recent decades (Frank and others, 1975, p. 77). These data seem to contradict Easterbrook's (1975, p. 681) suggestion that fumarolic activity diminished or ceased during the 1940's and 1950 's. Late-summer aerial photographs taken in 1940 and every year since 1956 show, in fact, that warm, snow-free ground has increased from about $5,500 \mathrm{~m}^{2}$ in 1940 to between 8,000 and $10,000 \mathrm{~m}^{2}$ in the past decade (Frank and others, 1977, p. 6).

\section{FUMAROLIC ACTIVITY BETWEEN 1970 AND 1974}

\section{SHERMAN GRATER FUMAROLE FIELD}

The Sherman Crater fumarole field, at 2,870-3,050 $\mathrm{m}$ altitude, is the larger of the thermal fields. Here, the most active pre-1975 fumaroles (Frank and others, 1977 , p. 6,8 ) were located within large ice-perforation features (figs. $5 A, 9$ ) just inside the east breach, a notch $200 \mathrm{~m}$ deep in the crater rim. Hydrothermal activity adjacent to Sherman Crater has effectively transformed rock in parts of the crater rim to clay-rich alteration products. Hydrothermally altered ground also extends beneath the crater glacier. A linear cluster of ice-perforation features (fig. $5 B$ ) that was present before March 1975 extended northward along the inside of the rim near a low point on the west rim of the crater. The area of the crater within the rim is estimated as $167,000 \mathrm{~m}^{2}$.

\section{DORR FUMAROLE FIELD}

The Dorr Fumarole Field (fig. 6) lies at 2,350-2,440 $\mathrm{m}$ altitude on the north slope of Mount Baker where William Henry Dorr first reported vapor emission in 1884 (Frank and others, 1977, p. 3-4).

The Dorr Fumarole Field was selected for temperature monitoring via a thermistor array and Landsat data collection platform for a year-long experiment (Landsat-1 expt. SR 251) in 1972. From 1972 through 1974, this experiment revealed no significant changes in activity at the Dorr Fumarole Field, and none was observed during ground investigations. Similarly, no significant changes in the area of snow-free ground are apparent in aerial photographs from 1958 through 1974. The presence of fumaroles suggests that the Dorr Field once may have been the site of eruptive activity, although no vent has yet been identified there.

\section{INCREASE IN FUMAROLIC ACTIVITY IN 1975}

The increase in fumarolic activity in 1975 in Sherman Crater, including new areas of heat emission and expansion of old areas of heat emission, is well documented by Frank, Meier, and Swanson (1977, p. 1, 8-13, and 28-29).

\section{SURVEILLANCE AND MAPPING BY AERIAL INFRARED SCANNER}

Seven aerial infrared survey missions were undertaken under the auspices of the U.S. Geological Survey between 1970 and 1973. Table 1 summarizes these aerial infrared missions, and figure 7 is a block diagram of the RS-14 scanner operated over Mount Baker on November 20,1972. These missions were designed to map the distribution, size, and geometry of surface thermal manifestations, to determine changes in intensity of thermal radiation from the surface, and to derive the differential radiant-flux density. For a summary of aerial infrared surveys during 1975, see Frank, Meier, and Swanson (1977, p. 10-13).

\section{GEOLOGIC INTERPRETATION OF INFRARED IMAGES}

Thermal infrared images acquired in the aerial surveys show the distribution of pre-1975 surface heatflow anomalies (defined as areas where heat-flux density at the surface is greater than $8.4 \mathrm{~W} \mathrm{~m}^{-2}$ or $200 \mu \mathrm{cal}$ $\mathrm{cm}^{-2} \mathrm{~s}^{-1}$ ) within Sherman Crater (fig. 8) and Dorr Fumarole Field. The Sherman Crater anomalies (fig. 9) formed a semicircle at the inner base of the crater rim (fig. 10). These anomalies (fig. 11A, 11B) included a cluster that coincided with the most intensive fumarolic activity associated with ice perforations near the east breach of the crater.

Concentration of intense thermal emission in the old fumarole clusters of the east-breach area is also substantiated by the 1972 isodensity scans. Abundant field evidence, supplemented by infrared image analyses that show the surface geometry of the east-breach anomalies, led to the inference that the east-breach area "apparently overlies the most direct permeable

TABLE 1.-Thermographic surveys over Mount Baker, Wash., before 1975

[All missions were flown on behalf of the U.S. Geological Survey; the spectral region sensed was 8-14 $\mu \mathrm{m}$; and RS-7 infrared scanners were used on all missions except that of Nov. 20,1972, which used an RS-14 scanner]

\begin{tabular}{lcc}
\hline \multicolumn{1}{c}{ Date } & \multicolumn{1}{c}{ Time } & Agency flying mission \\
\hline Nov. 4, 1970 & $0737-0806$ P.d.t. & U.S. Forest Service, Boise, Idaho \\
Apr. 3, 1971 & $2118-2132$ P.d.t. & Do. \\
Aug. 7, 1971 & $0214-0226$ P.d.t. & Do. \\
Apr. 22, 1972 & $2020-2047$ P.d.t. & U.S. Forest Service, Missoula, Montana \\
July 21-22, 1972 & 2351-0020 P.d.t. & Do. \\
Nov. 20, 1972 & $0301-0350$ P.s.t. & Johnson Space Center, Houston, Texas \\
Apr. 29, 1973 & 0432-0457 P.d.t. & U.S. Forest Service, Missoula, Montana \\
& &
\end{tabular}




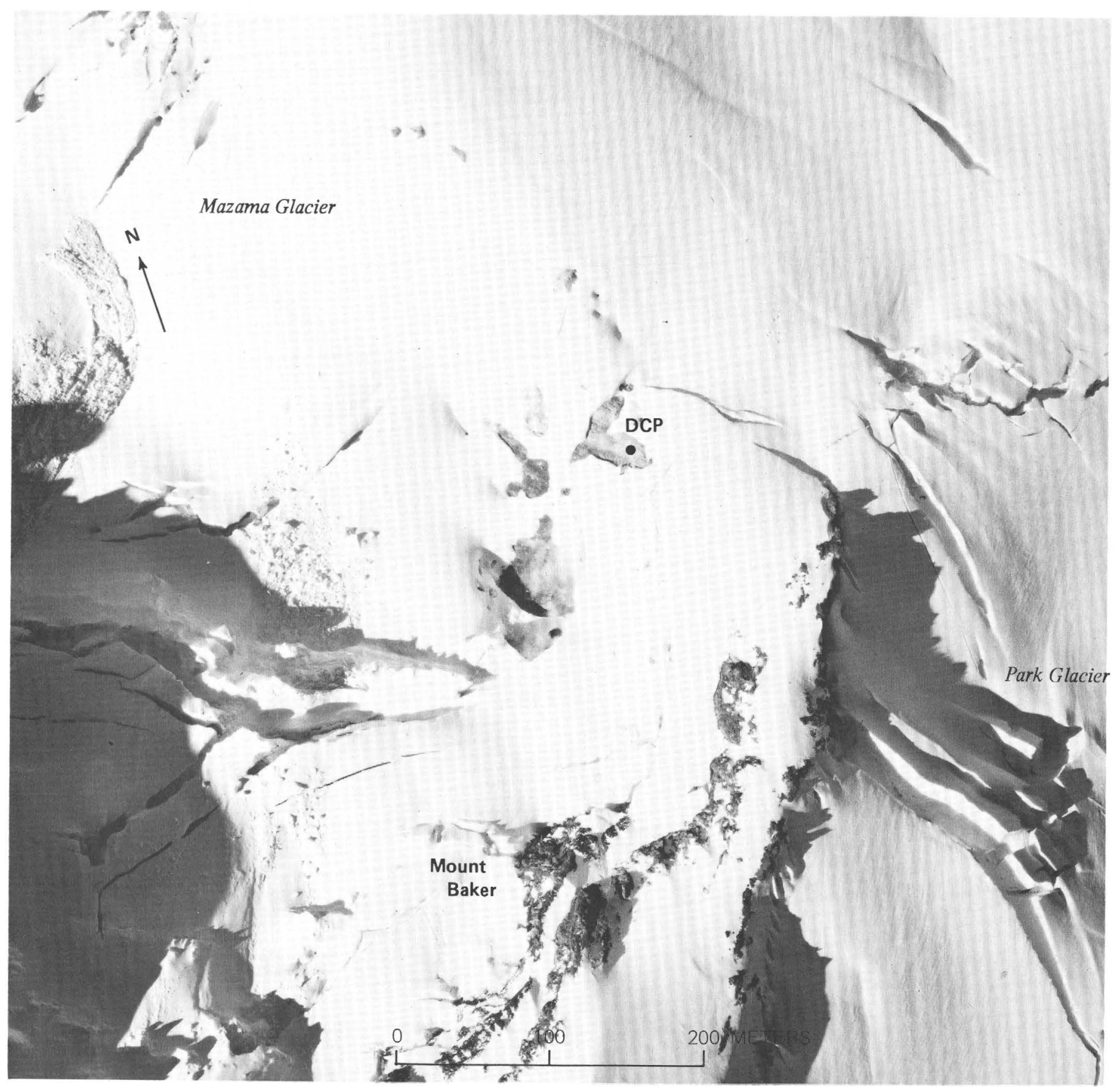

Figure 6.-Vertical view of the Dorr Fumarole Field on the north slope of Mount Baker, June 10, 1975. The location of Landsat Data Collection Platform (DCP) 6251 is shown at the edge of an icemelt feature. Photograph 75 MB1-25 by R. M. Krimmel.

path from the volcanic heat source" (Frank and others, 1977, p. 17), as evidenced by the presence of the hottest and largest fumaroles, the concentration of activity in this area during historic time, and by the presence of the east breach itself.

Aerial infrared images obtained in 1975 (Eichelberger and others, 1976; Rosenfeld, 1976) show a second trend superimposed on the older pattern: an eastwest trend within the crater, which is represented by linear alinements of new fumaroles and new thermal activity extending downslope from the west rim (Frank and others, 1977, p. 17).

The surface area of anomalously warm ground in Sherman Crater, according to the last two infrared surveys listed in table 1 , ranged from $8,800 \mathrm{~m}^{2}$ in November 1972 to $7,500 \mathrm{~m}^{2}$ in April 1973. The maximum thermal area exposed at the Dorr Field, as recorded in these same surveys, is about $3,020 \mathrm{~m}^{2}$ (fig. 


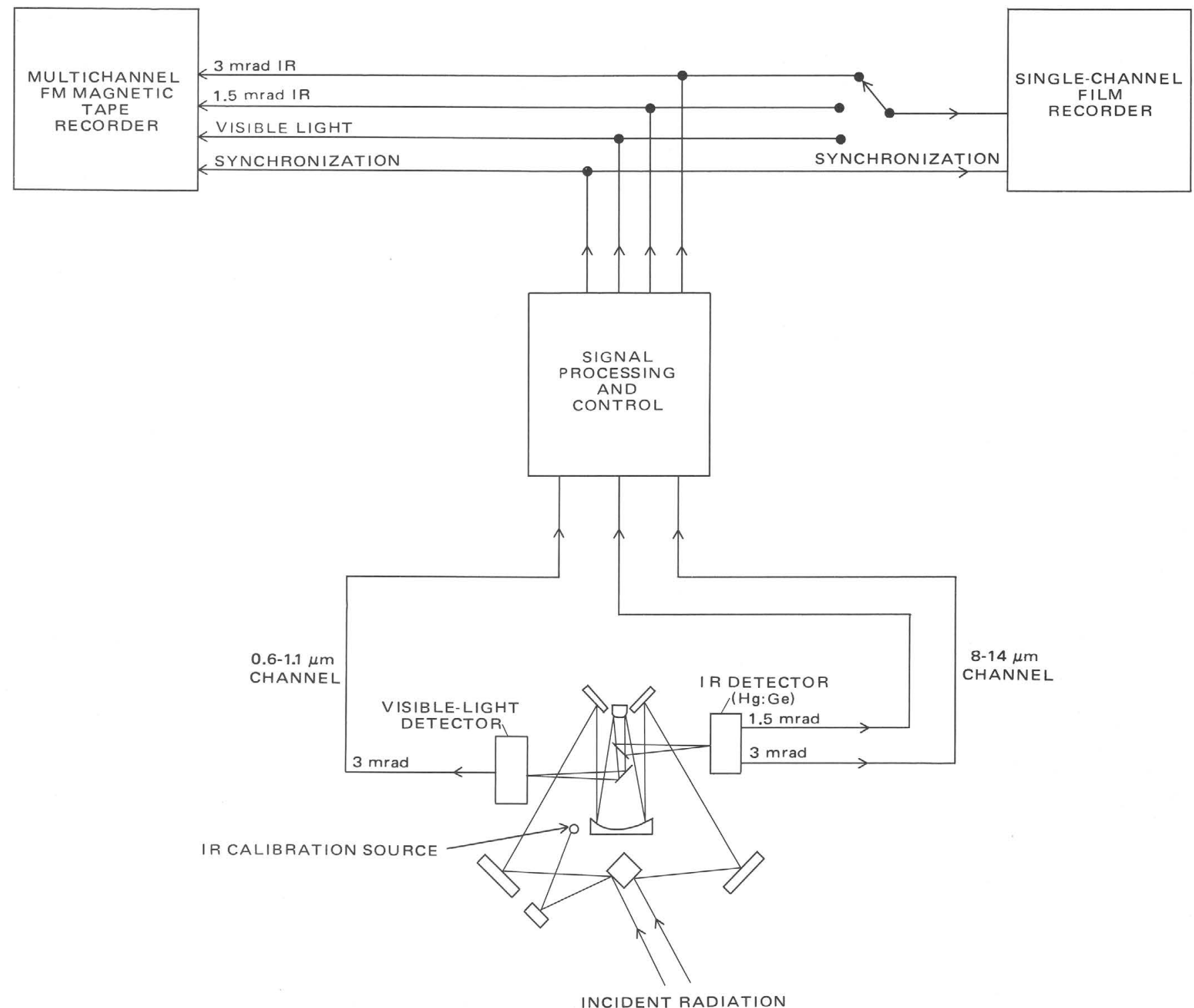

FigURE 7.-Schematic diagram of airborne scanner used in the aircraft mission over Mount Baker Nov. 20, 1972. A Hg:Ge detector sensitive to radiation in the $8-14 \mu \mathrm{m}$ range was used, and both videotape and film coverage were obtained.

11C). It is significant that the minimum thermal area recorded in the surveys of April 1973 was 90 percent of the maximum thermal area recorded in July and November of the same year. April is the period of near-maximum snow cover in the Mount Baker area.

The relative effect of survey flight altitude is illustrated by the fact that the highest altitude survey (3,075 $\mathrm{m}$ above the crater on July 21,1972$)$ recorded few thermal details in the major areas, whereas the lowest altitude survey ( $770 \mathrm{~m}$ above the crater on April $29,1973)$, which used the same line scanner, recorded for the first time two apparent point-source anomalies at the base of Lahar Lookout. These two anomalies actually correspond to small ice perforations that resulted from subglacial heat emission. The perforations are visible in all aerial photographs examined dating back to 1940 .

\section{RADIANT-FLUX ESTIMATION}

The radiant flux emitted from one surface can be compared to that from another nearby surface, and the differential radiant flux can be estimated by application of a two-point thermal model. (See Birnie, 1973; Friedman and others, 1976, p. 650.)

Specifically, the differential radiant exitance $\mathrm{Wd} \lambda$ (the differential power radiated per unit area from the Earth's surface) can be approximated by Stefan's fourth-power law, according to which a body at absolute temperature $T_{1}$, surrounded by a black enclosure whose walls are at absolute temperature $\mathrm{T}_{2}$, will lose 



Figure 8.-Infrared images of Sherman Crater from April 1971 to April 1973 (black, cool; white, warm). A, April 3, 1971, 2118-2132 P.d.t.; $B$, April 22, 1972, taken 2020-2047 P.d.t.; C, November 20, 1972, 0301-0350 P.s.t.; and D, April 29, 1973, 0432-0457 P.d.t. The general pattern of thermal activity recorded in these images was similar from 1971 to 1973 . The April images of $1971(A)$ and $1972(B)$ show less apparent thermal activity because of unusually heavy winter snowfall in comparison to that of April $1973(D)$. Image $C$, November 1972, represents the time of least snowcover during the U.S. Geological Survey infrared surveys. Fumaroles of the east breach indicated by eb. Image distortion is variable, but north is toward the top of each frame.

heat at the rate $\epsilon \sigma\left(\mathrm{T}_{1}{ }^{4}-\mathrm{T}_{2}{ }^{4}\right)$, where $\sigma$ is Stefan's constant and $\epsilon$ is the emissivity of the surface. $\mathrm{Wd} \lambda$ $\left(=\sim \mathrm{F}_{\mathrm{b}}\right.$, the differential radiant flux (in $\left.\mathrm{W} \mathrm{m}^{-2}\right)$ ) is derived from the Stefan-Boltzmann function via the following expression:

$$
\mathrm{Wd} \lambda=\epsilon 5.679 \times 10^{-8}\left(\mathrm{~T}_{1}^{4}-\mathrm{T}_{2}{ }^{4}\right)
$$

where emissivity $\epsilon$ is $0.95 \pm 0.04, \mathrm{~T}_{1}$ is the integrated kinetic temperature of an individual mapped radiometric unit from the infrared images, and $\mathrm{T}_{2}$ is $273 \mathrm{~K}$, the standard reference surface, equivalent to kinetic temperature of the adjacent ground-ice interface. The differential radiant flux above $273 \mathrm{~K}$, for conditions prevailing at Mount Baker on November 20, 




Figure 9.-Vertical view of Sherman Crater and crater glacier, September 3, 1963. Photograph 8-V635 by Austin Post. 


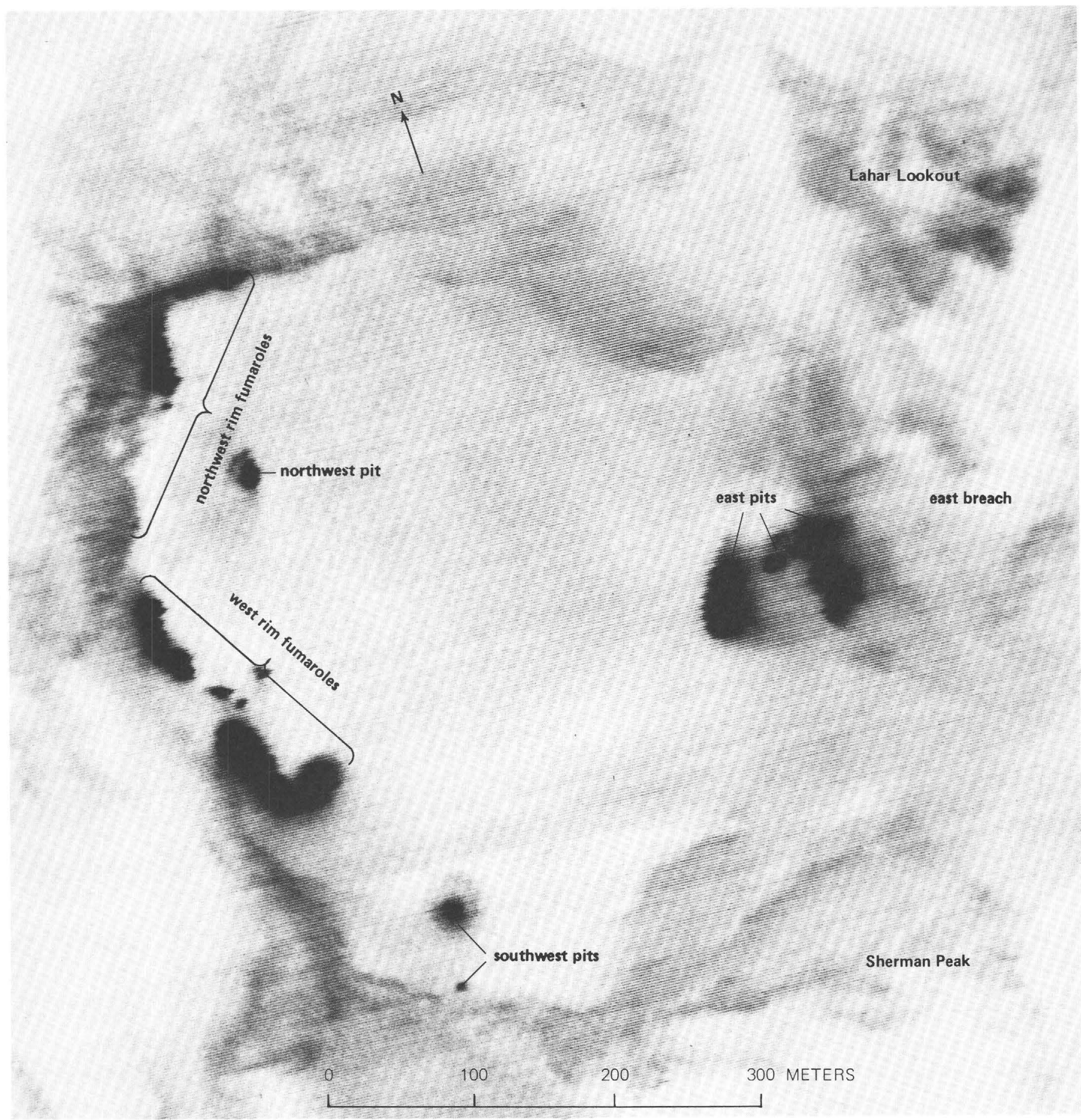

FIGURE 10.-Infrared image of November 20, 1972, enlarged to show relationship of thermal features of Sherman Crater to ice perforations and fumarole clusters of fig. 9 . Note reversal of image polarity-black, warm; white, cool. 
1972 , is plotted as a function of kinetic ground temperature in figure 14.

\section{CORRECTIONS FOR ABSORPTION AND EMISSION BY ATMOSPHERIC WATER VAPOR, CARBON DIOXIDE, AND AEROSOLS}

The effective atmospheric absorption of radiation in the $8-14 \mu \mathrm{m}$ region has been plotted by Saunders (1970, p. 7598) as a function of water-vapor mixing ratio in the air column for a relative humidity of 70 percent.

For an atmospheric pathlength of $1 \mathrm{~km}$, under the conditions prevailing on November 20, 1972 (mean transmission-path air temperature of $265.1 \mathrm{~K}){ }_{1}^{1}$ absorption in the 8-14 $\mu \mathrm{m}$ region by water vapor would be approximately 15 percent, $\mathrm{CO}_{2}$ would absorb roughly 1 percent, and aerosol absorption would be a small fraction of a percent, using a standard model atmosphere (McClatchey and others, 1972, p. 60-61, 62, 68; Gebbie and others, 1951), or Saunders' plot (1970, p. 7598).

The average transmission pathlength $\mathrm{z}$ for the RS-14 scanner used in the Mount Baker surveys of November 20,1972, approximates a simple function of the vertical pathlength $\mathrm{x}$ and the half-scan angle $\mathrm{a}$ in which

$$
\mathrm{z}=\mathrm{x} / \cos (\mathrm{a} / 2)
$$

On November 20, 1972, the vertical path, $\mathrm{x}$, was $1,040 \mathrm{~m}$ between the Sherman Crater fumarole field and the survey aircraft traverse altitude of $4,000 \mathrm{~m}$ m.s.l. The average transmission pathlength $\mathrm{z}$ was thus $1,106 \mathrm{~m}$, equivalent to an overall atmospheric absorption of 17.7 percent.

\section{TEMPERATURE CORRECTIONS FOR SURFACE FMISSIVITY}

Conversion of effective radiometric ground-surface temperature derived via the Stefan-Boltzmann function from calibrated infrared (8-14 $\mu \mathrm{m}$ region) images to ground kinetic temperature $(\nu)$ can be approximated by the relation

$$
\epsilon^{1 / 4} v=\mathrm{T}
$$

where $\epsilon$ is the effective surface emissivity and $\mathrm{T}$ is the radiometric surface temperature in kelvins.

\footnotetext{
'The integrated temperature of the transmission path was approximated by radiosonde data recorded at the Quillayute weather station, Washington ( $47^{\circ} 57^{\prime} \mathrm{N}^{\prime}, 124^{\circ} 33^{\prime} \mathrm{W}$.) at 1115 G.m.t., November 20, 1972 (U.S. National Climatic Center, Asheville, N.C.)
}

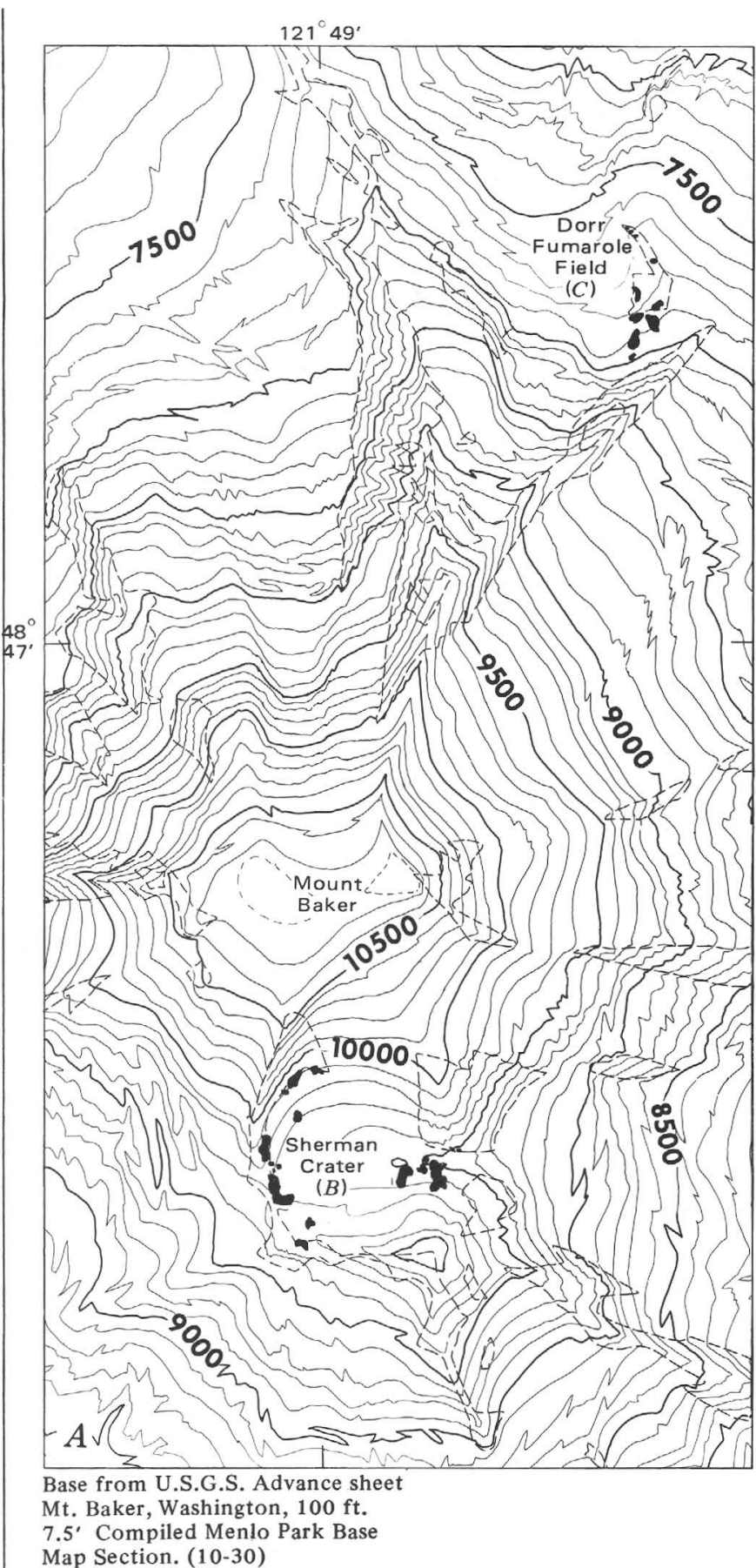

0

$1 / 2$

1 KILOMETER

FIGURE 11.-Planimetrically corrected distribution of anomalously warm areas of Sherman Crater and Dorr Fumarole Field, Mount Baker, 1972. $A$ is compiled from infrared images and plotted on a topographic base; elevations given in feet $(100 \mathrm{ft}=30.5 \mathrm{~m}) ; B$, Sherman Crater isothermal map units derived from 10-step calibrated infrared image of November 20,1972, and image-density scans; and $C$, Dorr Fumarole Field isothermal map units derived from 10-step calibrated infrared image of November 20, 1972, and image-density scans. 


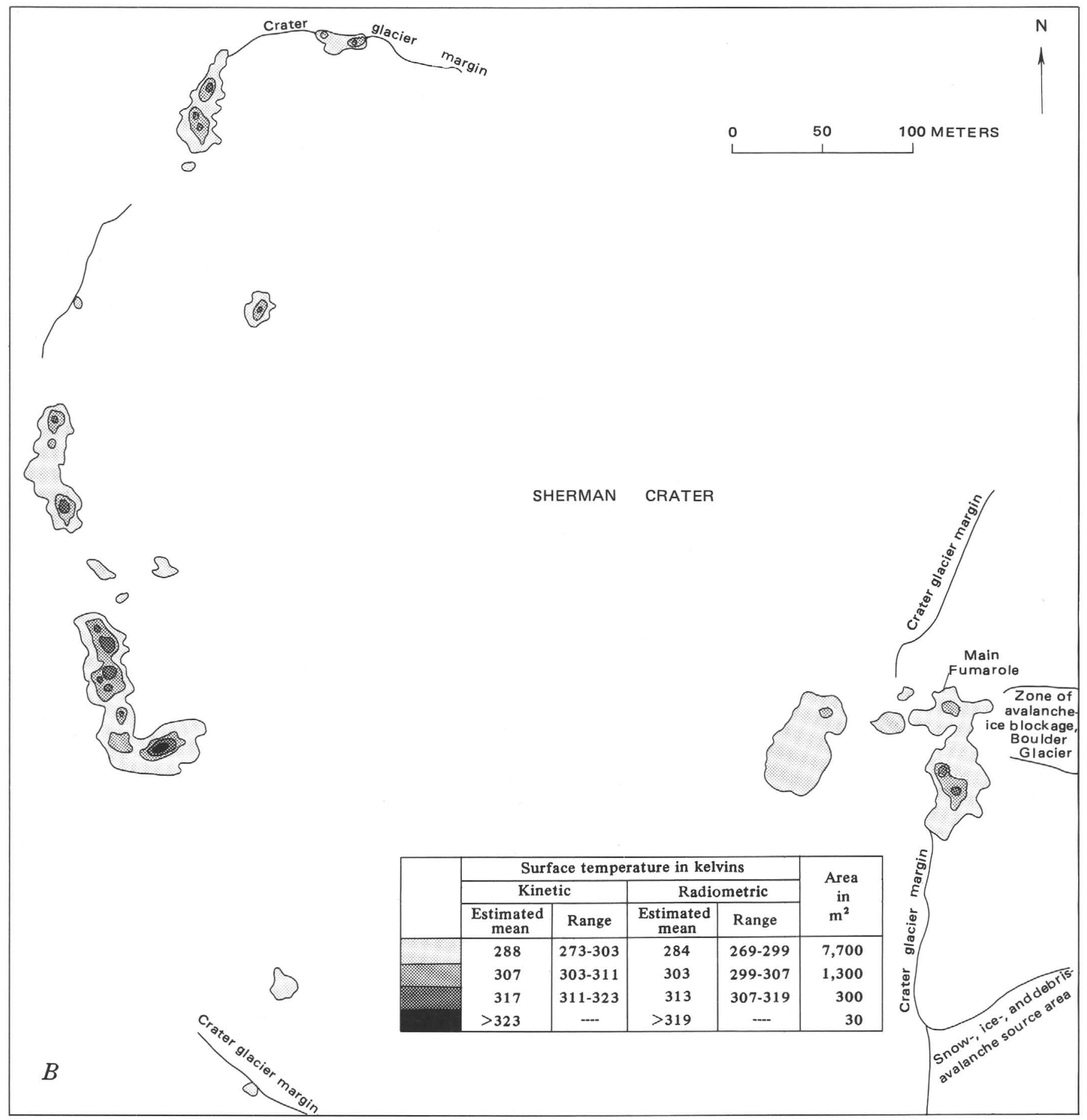

Figure 11.-Continued.

A collection of 38 polished sections of California volcanic rock types, ranging in composition from mafic to silicic, was reported to range in $\epsilon_{8-14 \mu} \mathrm{m}$ from 0.868 to 0.985 , averaging 0.946 (Daniels, 1968, p. 74-78). For rough and natural weathered surfaces the effective emissivity of volcanic rock types approaches 1.0 asymptotically with increased roughening, as implied by the work of Gouffe (1945), who showed that the change in effective emissivity (in the 8-14 $\mu \mathrm{m}$ region) of a surface is a function of cavity shape and integrated emissivity of cavity walls. Vicker and Lyon (1967) have also pointed out that for most soils, the effect of reduc- 


\begin{tabular}{|c|c|c|c|r|}
\hline \multirow{2}{*}{} & \multicolumn{2}{|c|}{ Surface temperature in kelvins } & \multirow{2}{*}{$\begin{array}{c}\text { Area } \\
\text { in } \\
\mathrm{m}^{2}\end{array}$} \\
\cline { 2 - 4 } & $\begin{array}{c}\text { Estimated } \\
\text { mean }\end{array}$ & Range & $\begin{array}{c}\text { Radiometric } \\
\text { (Range) }\end{array}$ & \\
\hline & 288 & $273-303$ & $269-299$ & 2,520 \\
\hline & 307 & $303-311$ & $299-307$ & 460 \\
\hline & $\geqslant 317$ & $>311$ & $>307$ & 40 \\
\hline
\end{tabular}

\begin{tabular}{|c|c|c|c|c|c|c|}
\hline \multirow{3}{*}{ Locality } & \multirow{3}{*}{$\begin{array}{c}\text { Sample } \\
\text { Type }\end{array}$} & \multirow{3}{*}{$\begin{array}{c}\text { Area } \\
\text { in } \\
\mathrm{m}^{2}\end{array}$} & \multicolumn{4}{|c|}{ Temperature in kelvins, taken by } \\
\hline & & & \multirow{2}{*}{$\begin{array}{c}\text { Bimetal } \\
15 \mathrm{~cm}\end{array}$} & thermometer & \multicolumn{2}{|c|}{$\begin{array}{l}\text { PRT-10 } \\
\text { at surface }\end{array}$} \\
\hline & & & & $<1 \mathrm{~cm}$ & Mean & Range \\
\hline A & $\begin{array}{l}\text { Solar-heated } \\
\text { rock }\end{array}$ & $\cdots$ & $-\cdots$ & $-\cdots$ & 287 & $\cdots$ \\
\hline B & $\begin{array}{l}\text { Soil } \\
\text { Soil } \\
\text { Steam }\end{array}$ & $\begin{array}{c}75 \\
4 \\
\end{array}$ & $\begin{array}{l}333 \\
311 \\
363 \\
\end{array}$ & $\begin{array}{c}303 \\
294 \\
--- \\
\end{array}$ & $\begin{array}{r}294 \\
303 \\
--- \\
\end{array}$ & $\begin{array}{c}284-313 \\
--- \\
--\end{array}$ \\
\hline $\mathrm{C}$ & Soil & $\ldots$ & 349 & 320 & -.-- & -..- \\
\hline D & $\begin{array}{l}\text { Soil } \\
\text { Soil }\end{array}$ & 1,400 & $\begin{array}{l}355 \\
321\end{array}$ & $\begin{array}{l}316 \\
301\end{array}$ & 308.5 & $\begin{array}{c}301-316 \\
\ldots\end{array}$ \\
\hline $\mathrm{E}$ & $\begin{array}{l}\text { Soil } \\
\text { Soil } \\
\text { Soil marginal } \\
\text { to snow } \\
\quad \text { Shaded } \\
\quad \text { Sunlit } \\
\end{array}$ & --- & $\begin{array}{l}358 \\
323\end{array}$ & $\begin{array}{l}299 \\
293\end{array}$ & $\begin{array}{l}296 \\
293 \\
\\
276 \\
283 \\
\end{array}$ & $305-319$ \\
\hline $\mathrm{F}$ & Soil & $-\cdots$ & ---- & $\ldots$ & 305 & --.- \\
\hline $\mathrm{G}$ & $\begin{array}{l}\text { Water pools } \\
\text { Steam }\end{array}$ & $<50$ & 364 & 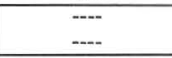 & $\begin{array}{r}314 \\
\cdots\end{array}$ & $\begin{array}{c}311-317 \\
\ldots\end{array}$ \\
\hline
\end{tabular}

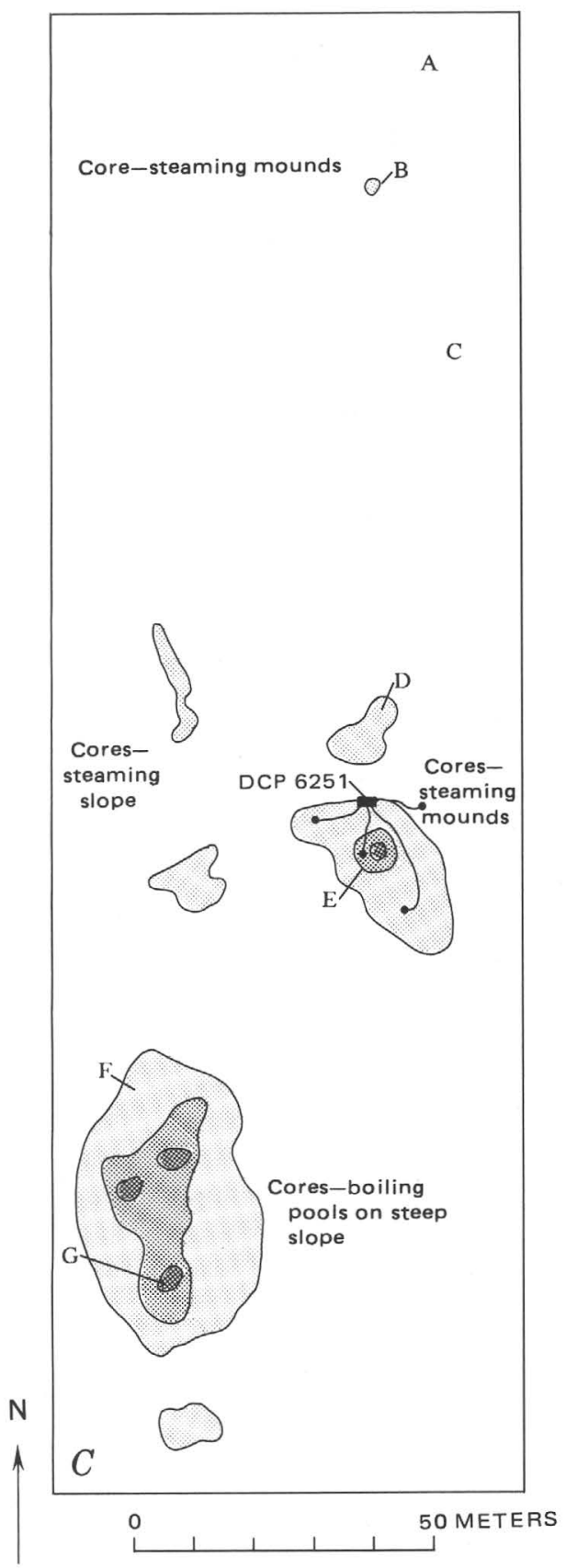

Figure 11.-Continued.

ing grain size is to diminish the spectral contrast and raise the emissivity in the $8-14 \mu \mathrm{m}$ region, producing a fairly constant value of 0.95 .

Accordingly, for the fresh and altered andesitic surfaces and hydrothermal alteration products of Mount Baker, we assume the effective $\epsilon_{8-14 \mu \mathrm{m}}$ is $0.95 \pm 0.04$, and for water surfaces the effective $\epsilon_{8-14 \mu \mathrm{m}}$ is $0.99 \pm$ 0.01 (Saunders, 1970, p. 7599).
THERMOGRAPHIC SURVEY OF NOVEMBER 20, 1972

Calibrated infrared images were obtained from a series of traverses flown for this experiment (Landsat-1 SR 251) by the National Aeronautics and Space Administration NP3-A earth resources aircraft, using a dual channel RS-14 line-scan system (fig. 7) equipped with internal blackbody temperature references, mercury-doped germanium detectors, and a 10 -step 


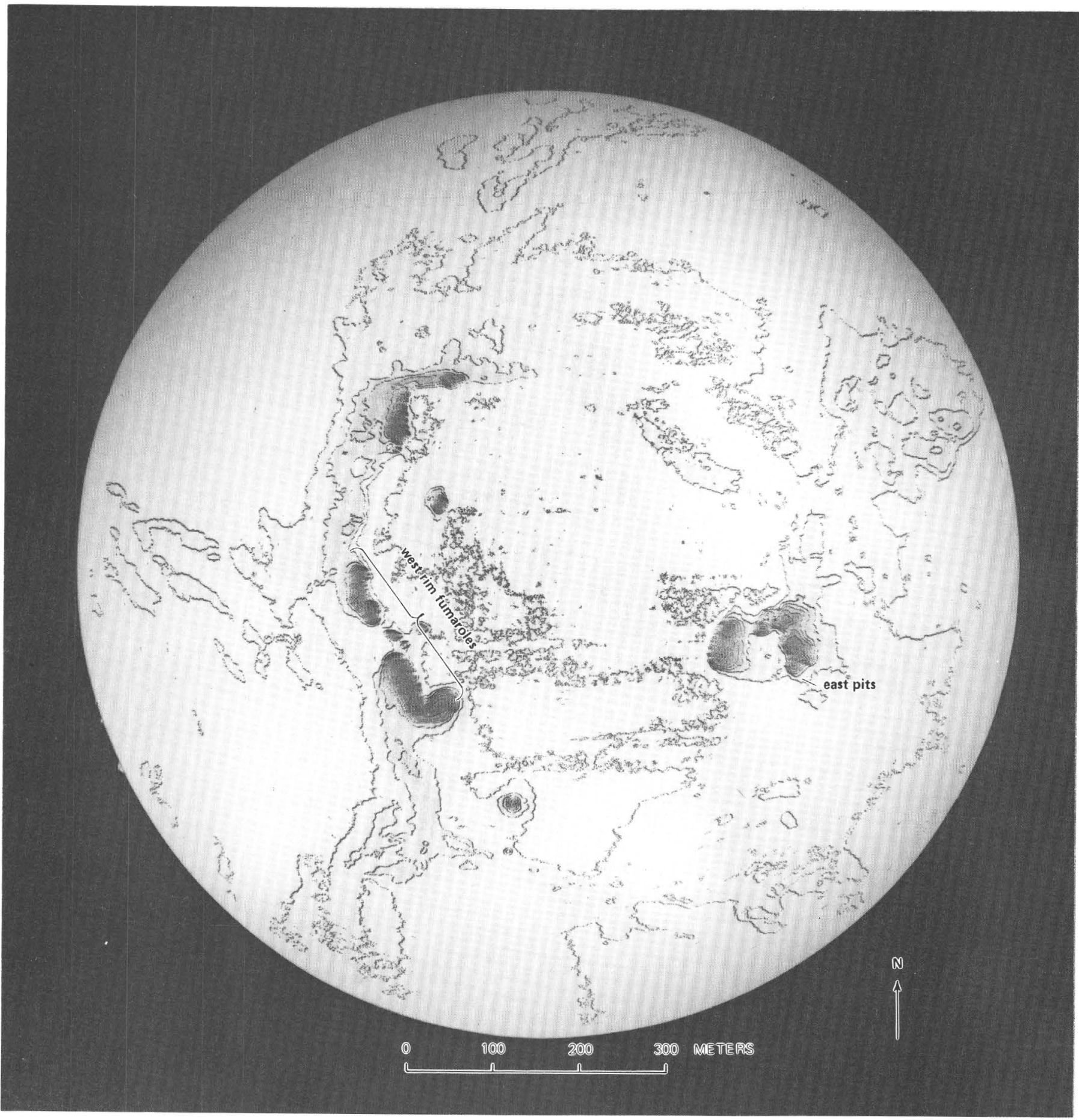

Figure 12.-Isodensity scan of infrared image shown in fig. 10, taken November 20, 1972. Magnification of film image $5 \times$; density-scan interval $0.12-0.20$ of the total density range of the image.

gray-scale calibration strip. One channel was operated in a display mode, producing an intensity-modulated trace on a 5-inch cathode-ray tube in a recording unit that was optically coupled to a film magazine unit. The thermographic images that gave a two-dimensional representation of uncorrected radiometric tempera- tures ranging from $294 \mathrm{~K}$ to $373 \mathrm{~K}$ were recorded on film, and uncalibrated images that encompassed the total temperature range of the system were recorded on videotape.

The infrared images were compared with the 10 -step gray scale by means of an image-density scan (fig. 12) 
and were thus contoured for radiometric surfacetemperature levels. The scan was prepared on an $\mathrm{EDP}^{2}$ scanning microscope, at magnifications of $1.8,5,10$, and $50 \times$, at apertures from 100 to $200 \mu \mathrm{m}$, and at density-scan intervals of 0.12 to 0.20 of the total density range of the image. Estimates of differential radiant-flux density of the east breach area, the entire Sherman Crater, and the Dorr Fumarole Field, given in table 2, were derived from these scans, converted to ground kinetic temperature, and corrected for planimetric distortion of the area of the anomalies on the video-processed images. Planimetric corrections for linear image distortion were made in plotting figure 11.

Of the total $8,800 \mathrm{~m}^{2}$ of anomalously warm ground in Sherman Crater, as measured by this method, $3,600 \mathrm{~m}^{2}$ is included in the east-breach cluster of anomalies and much of the remainder is in the west-rim sector. Table 2 gives the kinetic ground temperatures and areas of the infrared anomalies. The integrated background radiometric temperature for adjacent cold, high-albedo ice surfaces averaged $255 \mathrm{~K}$, as measured from the NP3-A aircraft by a Barnes PRT-5 infrared radiometer on November 20, 1972. However, for purposes of radiometric comparison with adjacent nonthermal ground, which is essential in application of the twopoint thermal model, the relatively constant kinetic ground temperature of $273 \mathrm{~K}$ at the ground-ice interface approaches the mean annual temperature and was used in the present investigation as the standard reference. ${ }^{3}$

The inference that $273 \mathrm{~K}$ is very close to the constant ground-ice interface temperature at the periphery of the ice perforations in the crater glacier is supported by temperature measurements by E. P. Kiver (oral commun., 1976) and by data reviewed by Robin (1976, p. 186) for ground and air temperature below temperate glaciers. Theakstone (1967), for example, reported that air temperature in a tunnel beneath $50 \mathrm{~m}$ of ice near the margin of Østerdalsisen in Norway remained almost constant at $-1.0^{\circ} \mathrm{C}$, and Vivian and Bocquet (1973, p. 441) reported air temperatures which vary a little around $+0.5^{\circ} \mathrm{C}$ in ice tunnels they studied beneath Glacier d'Argentière at Mount Blanc, France.

Table 2 gives the radiant-flux density in relation to adjacent 273-K surfaces at Mount Baker.

\footnotetext{
"Use of trade names in this report is for descriptive purposes only and does not constitute endorsement by the U.S. Geological Survey.

3The mean annual air temperature at Sherman Crater (at 2,960 m m.s.l.) is close to 272.6 $\mathrm{K}$, based on the mean annual temperature of $277.65 \mathrm{~K}$ ( $1 \mathrm{~m}$ above ground) recorded at an elevation of $1,277 \mathrm{~m}$ m.s.l. at Heather Meadows Recreational Area (data from U.S. National Climatic Center, Asheville, N.C., 1976) and an interpolated moist adiabatic lapse rate (see Brunt, 1939, p. 66) of $0.003 \mathrm{~K} \mathrm{~m}^{-1}$, which roughly corresponds to a relative humidity of 72 percent. Radiosonde data for 1115 G.m.t., November 20 , 1972, at $47^{\circ} 57^{\prime}$ N., $124^{\circ} 33^{\prime}$ W indicated a lapse rate of $0.0035 \mathrm{~K} \mathrm{~m}^{\prime}$ and an air temperature of $268.2 \mathrm{~K}$ at $2,960 \mathrm{~m}$ m.s.l
}

Aerial infrared surveys similar to those reported here were carried out in 1975 and 1976 by Rosenfeld (1976) (fig. 13). We have derived radiant-flux estimates from Rosenfeld's data, using the same two-point method that was used for the 1972 infrared data; these are given in table 2. (See also fig. 14.)

\section{ELECTRONIC THERMAL-SENSOR ARRAY AND LANDSAT DATA COLLECTION PLATFORM}

The Landsat-1 Data Collection Platform 6251, designed specifically for kinetic temperature monitoring at Mount Baker, was installed at the Dorr Fumarole Field at approximately $48^{\circ} 45^{\prime}$ N., $121^{\circ} 40^{\prime}$ W. at 2,400 $m$ m.s.l.; it transmitted data successfully from February 8, 1973, to March 15, 1974. A brief description of the typical thermistor-array DCP system and simplified schematic diagrams are given in Friedman, Preble, and Jakobsson (1976); a detailed description of the electronic thermal-sensor system and related data-collection-platform technology is given in Preble, Friedman, and Frank (1977).

Sensor-probe sites, specifications for DCP 6251, and mean kinetic temperatures between February 8 and March 17, 1973, are given in table 3, and kinetic temperature variations for this same period are plotted in figure 15.

\section{HEAT-FLUX ESTIMATES}

The geothermal flux in the vegetation-free anomalous temperature zones at Mount Baker is considered to be related to the other major components of the heat budget of the ground surface by the following equation:

$$
\mathrm{Q}=\mathrm{F}_{\mathrm{b}}+\mathrm{F}_{\mathrm{h}}+\mathrm{F}_{\mathrm{e}}+\mathrm{F}_{\mathrm{ad}}
$$

where $\mathrm{Q}$ is the net geothermal flux; $\mathrm{F}_{\mathrm{b}}$ is the differential radiant flux relative to $273 \mathrm{~K}$ (that is, $\mathrm{F}_{\mathrm{b}}$ approximates the outgoing radiant flux minus the absorbed solar flux, minus nondirectional or diffuse sky radiation, minus heat flux in the ground that results from solar radiation); $F_{h}$ is the outgoing flux of energy from the surface by eddy diffusion and molecular conduction; $F_{\mathrm{e}}$ is the heat flux lost to the atmosphere by evaporation; and $\mathrm{F}_{\mathrm{ad}}$ is the heat flux carried out of the area advectively by ice melt, by stream runoff, and by mass transfer to the atmosphere via fumarole and vaporplume emanations.

In the present investigation, the differential geothermal flux (that flux corresponding to kinetic temperatures higher than $273 \mathrm{~K}$, the ground-ice interface temperature at Mount Baker's Sherman Crater) is estimated by use of a two-point physical model (similar to 
TABLE 2.-Differential radiant flux and nonadvective heat flux at Dorr Fumarole Field and Sherman Crater, Mount Baker, Wash.

[Based on density analysis of calibrated aerial infrared (8-14 $\mu \mathrm{m})$ images. Radiant flux calculated using the Stefan- Boltzmann function. Heat flux calculated using a two-point thermal model adapted from that of Sekioka and Yuhara (1974); excludes flux components from plume and fumarole emission and other advective heat losses. ......, not calculated]

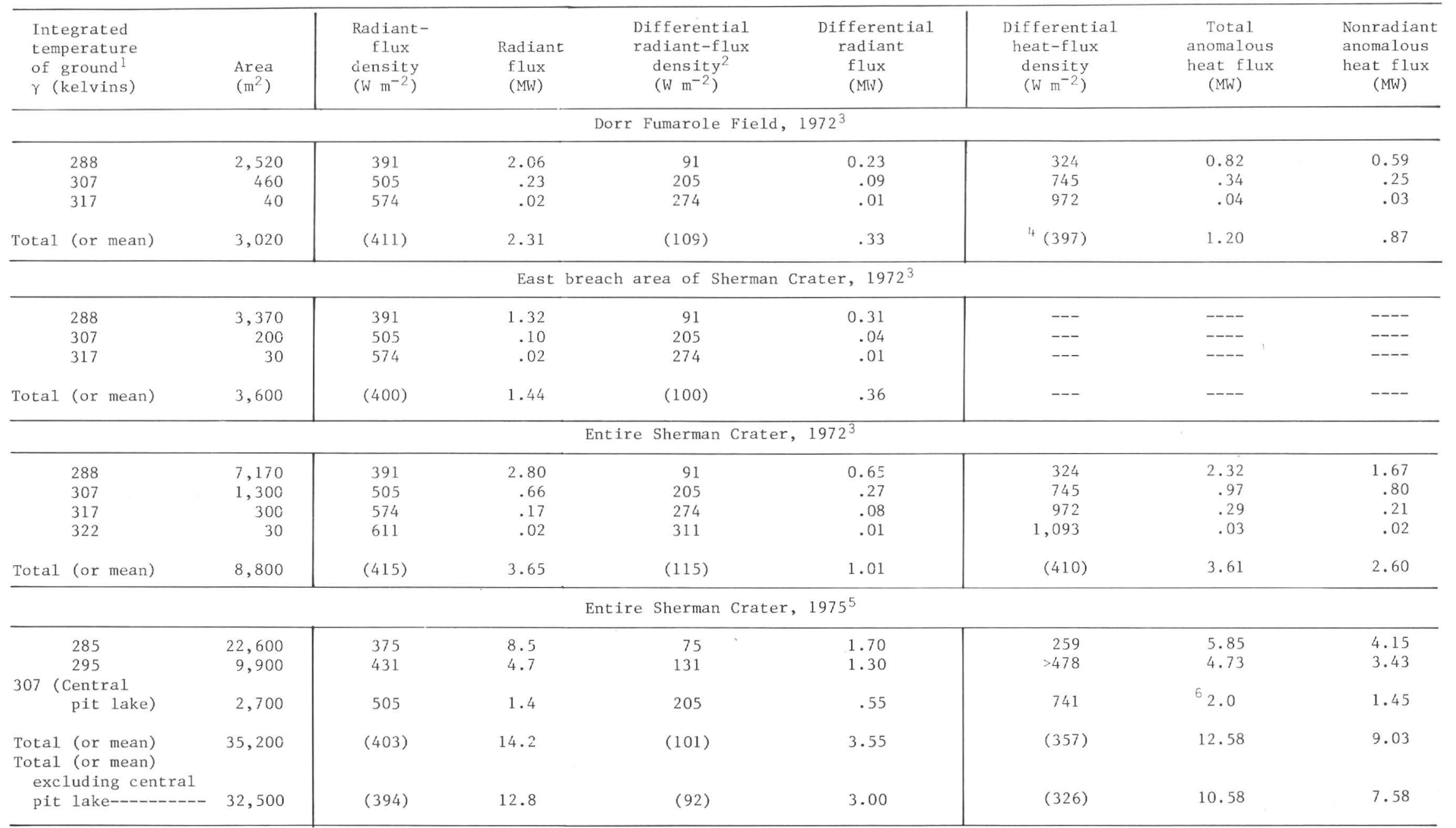

${ }^{1}$ Includes corrections for surface emissivity $(0.95+0.04)$ and atmospheric attenuation.

2 Relative to an adjacent $273-\mathrm{K}$ reference surface which has a radiant-flux density of $300 \mathrm{~W} \mathrm{~m}^{-2}$.

${ }^{3}$ Mission flown 0301-0350 P.s.t., Nov. 20, 1972, in NP3-A aircraft by Nat1. Aeronautics and Space Adm. Johnson Space Center using RS-14 infrared line scanner.

${ }^{4}$ Model of Dawson (1964) for convection-dominated systems gives average flux density of $287 \mathrm{~W} \mathrm{~m}^{-2}$ for DCP-thermistor $10 \mathrm{cations} 6$, 7 , and 8 , based

on 15 -cm-depth temperatures of 355 to $364 \mathrm{~K}$.

on 15-cm-depth temperatures of 355 to $364 \mathrm{~K}$.

Mission flown Aug. 24,1975 , in CV-1C
scanner (Rosenfeld, 1977 , p. 12-16)

${ }^{6}$ Compare with other estimates of total heat flow for central pit lake shown in table 4. 


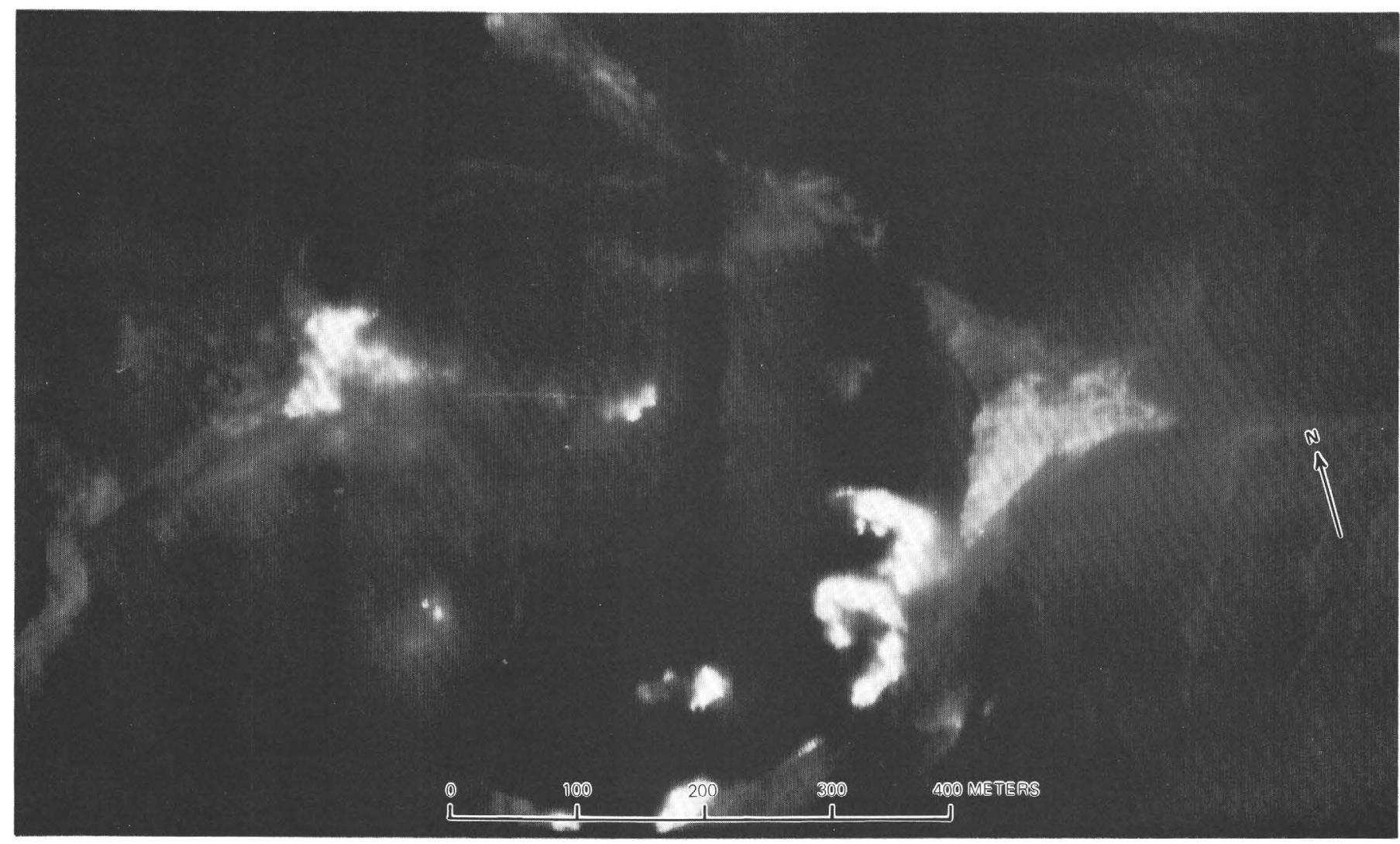

Figure 13.-Infrared image (8-14 $\mu \mathrm{m}$ range) of Sherman Crater, August 1975. Polarity: white, warm; black, cool. Note thermal emission from ice-perforation features. Part of west-facing slope of Sherman Crater appears warm as a result of direct solar irradiance late in the day. Image by Oregon National Guard.

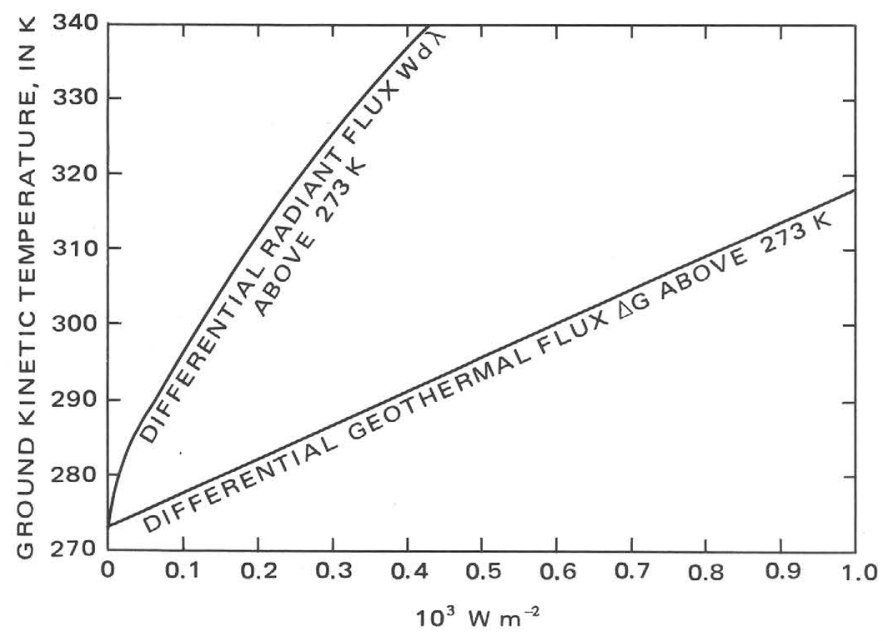

Figure 14.-The differential radiant exitance $(\mathrm{Wd} \lambda)$ in relation to a standard reference surface of $273 \mathrm{~K}$ plotted as a function of ground kinetic temperature for radiation conditions prevailing at Mount Baker, November 20, 1972. The differential geothermal flux (excluding advective heat loss) in relation to the same standard reference surface is also given as a function of ground kinetic temperature. the two-point differential radiance model) in which the two points selected are sufficiently close to have similar topography (slope), emissivity, albedo, and thermophysical properties of the ground surface. Following Sekioka and Yuhara (1974, p. 2055), we can express the difference between the geothermal fluxes at two adjacent places as a function of the difference between their corresponding surface temperatures, which can be measured simultaneously by an aerial infrared scanner as radiometric temperatures and converted to kinetic temperatures. The error introduced by assuming that emissivity, albedo, topography, and thermophysical properties of the surface are identical at the two points selected is considered to be less than the experimental error inherent in estimating the mean geothermal flux at the moderately high levels investigated. (See fig. 15 and table 6.)

The two-point model for heat balance of the ground surface for estimating moderate to high volcanogenic heat flows considers the following factors: (1) the net outgoing radiant flux (by subtracting the reflected shortwave radiation from the sum of the direct solar radiation and the nondirectional sky radiation), (2) the 
TABLE 3.-Thermal sensor array for Data Collection Platform 6251, Dorr Fumarole Field, Mount Baker, Wash.

[Data collected from Feb. 8, 1973, to Mar. 15, 1974, at $48^{\circ} 45^{\prime}$ N., $121^{\circ} 40^{\prime}$ W.; elevation $2,400 \mathrm{~m}$ m.s.l.]

\begin{tabular}{|c|c|c|c|c|c|c|c|c|c|c|}
\hline $\begin{array}{c}\text { DCP } \\
\text { analog } \\
\text { channel }\end{array}$ & $\begin{array}{l}\text { Sensor type } \\
\text { and number }\end{array}$ & Medium tested & $\begin{array}{l}\text { Distance } \\
\text { (m) and } \\
\text { direction } \\
\text { from } \\
\text { instrument } \\
\text { station }\end{array}$ & $\begin{array}{l}\text { Distance } \\
\text { above (+) } \\
\text { or helow } \\
(-) \text { ground } \\
\text { surface } \\
\quad(\mathrm{cm})\end{array}$ & $\begin{array}{r}\text { Sens } \\
\text { temper: } \\
\text { range } \\
\text { accu } \\
(0\end{array}$ & $\begin{array}{l}\text { or } \\
\text { ature } \\
\text { and } \\
\text { racy } \\
\text { C) }\end{array}$ & $\begin{array}{l}\text { Relationship of } \\
\text { temperature, T } \\
\left({ }^{\circ} \mathrm{C}\right) \text {, to output } \\
\text { voltage, } \mathrm{V}\end{array}$ & $\begin{array}{l}\text { Mean } \\
\text { temperature } \\
\text { Feb. } 8 \text { to } \\
\text { Mar. } 17,1973 \\
\left({ }^{\circ} \mathrm{C}\right)\end{array}$ & Variance & $\begin{array}{c}\text { Coefficient } \\
\text { of } \\
\text { variation } \\
\text { (on Celsius } \\
\text { scale) }\end{array}$ \\
\hline 1 & IA YSI 44203 & $\begin{array}{l}\text { Air inside instrument } \\
\text { station }\end{array}$ & 0 & +50 & -40 to & $60 \pm 2$ & $\mathrm{~T}=20(\mathrm{~V})-40$ & $0.10 \pm 2.11$ & 4.45 & 21.10 \\
\hline 2 & IB YSI 44203 & $\begin{array}{l}\text { Ambient air (in } \\
\text { shade) }\end{array}$ & 0 & +100 & -40 to & $60+2$ & $\mathrm{~T}=20(\mathrm{~V})-40$ & $-3.04+2.83$ & 8.01 & .93 \\
\hline 3 & IC YSI 44203 & $\begin{array}{l}\text { Marginally thermal } \\
\text { ground (under snow). }\end{array}$ & $2 \mathrm{E}$. & 0 & -10 to & $40+1$ & $\mathrm{~T}=10(\mathrm{~V})-10$ & $3.10 \pm 0.46$ & .21 & .15 \\
\hline 4 & ID $104 \mathrm{MB}$ & Fumarole vent-------- & $6 \mathrm{~W}$. & -15 & 30 to & $130 \pm 2$ & $\mathrm{~T}=20(\mathrm{~V})+30$ & $90.41+0.30$ & .09 & $<.01$ \\
\hline 5 & IIA $104 \mathrm{~B}$ & ----do-- & $2 \mathrm{~s}$. & -15 & 30 to & $130 \overline{+2}$ & $\mathrm{~T}=20(\mathrm{~V})+30$ & $91.20 \pm 0.14$ & .02 & $<.01$ \\
\hline 6 & IIB $104 \mathrm{MB}$ & Geothermal ground---- & $6 \mathrm{E}$. & -30 & 30 to & $130 \overline{+2}$ & $\mathrm{~T}=20(\mathrm{~V})+30$ & $80.77 \overline{+1} .00$ & 1.00 & .01 \\
\hline 7 & IIC YSI 44201 & ----do---on- & $6 \mathrm{E}$. & 0 & 18 to & $58 \overline{+1}$ & $\mathrm{~T}=8(\mathrm{~V})+18$ & $33.94+7.26$ & 52.65 & .21 \\
\hline 8 & IID $104 \mathrm{MB}$ & ----do-------------- & $6 \mathrm{E}$. & -50 & 30 to & $130 \pm 2$ & $\mathrm{~T}=20(\mathrm{~V})+30$ & $89.57 \pm 0.30$ & .09 & $<.01$ \\
\hline
\end{tabular}



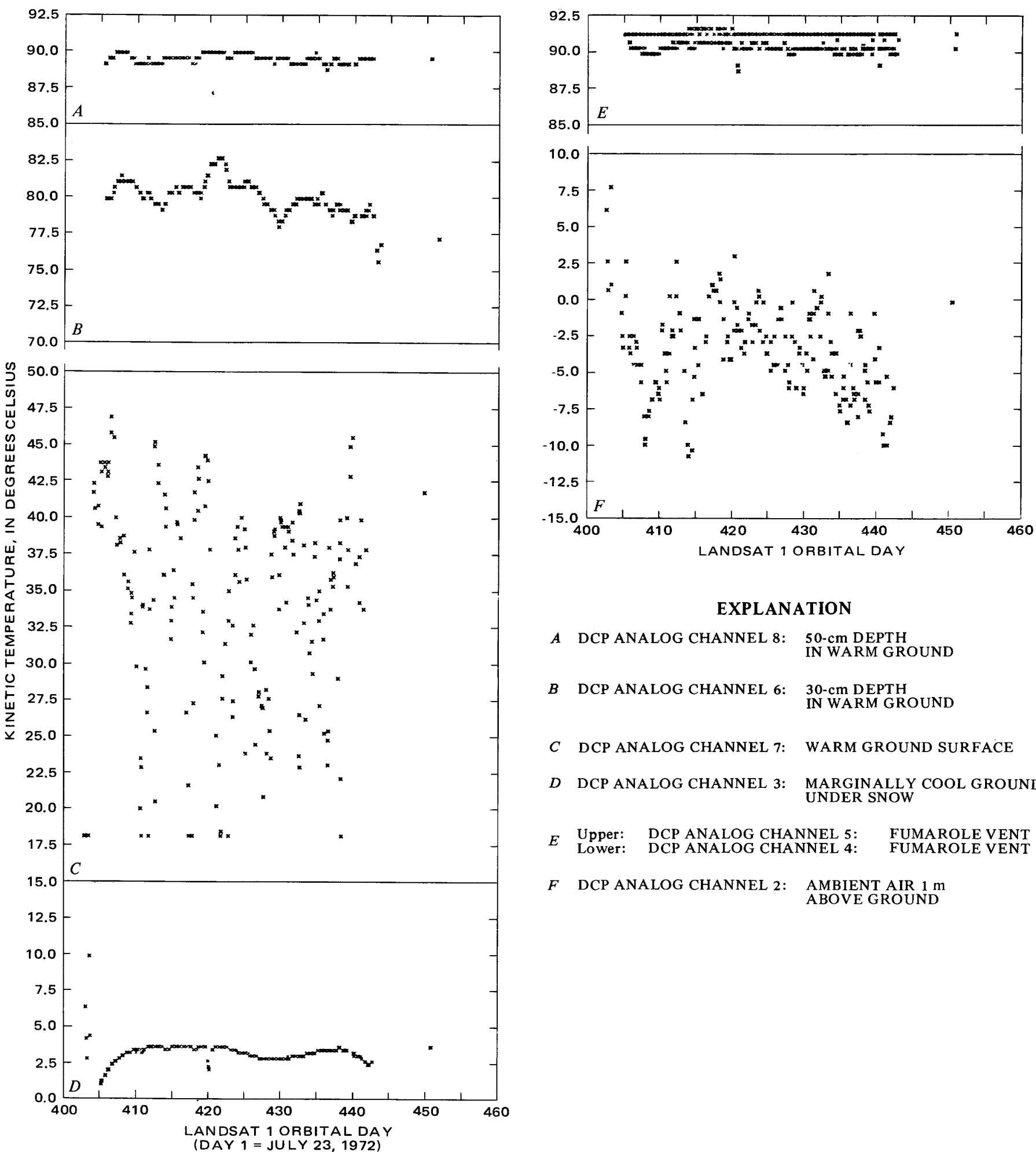

\section{EXPLANATION}
A DCP ANALOG CHANNEL 8: $50-\mathrm{cm}$ DEPTH
IN WARM GROUND
$\begin{array}{ll}B \text { DCP ANALOG CHANNEL 6: } & \text { 30-cm DEPTH } \\ \text { IN WARM GROUND }\end{array}$
C DCP ANALOG CHANNEL 7: WARM GROUND SURFACE
$D$ DCP ANALOG CHANNEL 3: MARGINALLY COOL GROUND UNDER SNOW
E Upper: DCP ANALOG CHANNEL 5: FUMAROLE VENT Lower: DCP ANALOG CHANNEL 4: FUMAROLE VENT

\section{ABOVE GROUND}
$F$ DCP ANALOG CHANNEL 2: AMBIENT AIR $1 \mathrm{~m}$

Figure 15.-Kinetic temperatures recorded by Landsat-1 Data Collection Platform 6251 at the Dorr Fumarole Field between February 8 and March 17, 1973. Electronic thermal probes recorded temperatures at $(A) 50-\mathrm{cm}$ depth and $(B) 30-\mathrm{cm}$ depth in the fumarole field, on a geothermally warmed surface $(C)$ (note scatter of temperature points caused by diurnal variations in micrometeorological conditions), and on a marginally warmed surface beneath a snowbank $(D)$. Nearly constant vapor-vent temperatures are also given for the same period $(E)$, as are ambient-air temperatures $1 \mathrm{~m}$ above the ground surface $(F)$. 
nocturnal radiation, (3) heat flow in the ground (positive or negative) due to solar radiation, (4) heat flow to the atmosphere via eddy diffusion, (5) evaporative heat exchange with the atmosphere, and (6) the geothermal flux. The two-point model permits the following simplified relationship (Sekioka and Yuhara, 1974, p. 2056):

$$
\begin{gathered}
\Delta \mathrm{G}=\epsilon(1-0.09 m)\left[0.52+0.065\left(\mathrm{e}_{\mathrm{w}}\right)_{\mathrm{r}_{2}}\right] \sigma\left(\Delta \mathrm{T}_{\mathrm{o}}\right)^{4} \\
+\rho_{\mathrm{a}} \mathrm{c}_{\mathrm{p}} \mathrm{D}(1+\lambda) \Delta \Theta
\end{gathered}
$$

in which the differential geothermal flux $\Delta G$ is expressed in terms of effective surface emissivity $\epsilon$ $(0.95 \pm 0.04)$, cloudiness $m$ ( 1 during the infrared surveys), vapor pressure $\mathrm{e}_{\mathrm{w}}(4.1 \mathrm{mbar})$, surface temperature $\mathrm{T}_{0}$ (in kelvins) and $\Theta\left({ }^{\circ} \mathrm{C}\right)$, air density $\rho_{\mathrm{a}}(0.909 \times$ $10^{-3} \mathrm{~g} \mathrm{~cm}^{-3}$ at $3,000 \mathrm{~m}$ m.s.l.), the specific heat of air at constant pressure $c_{\mathrm{p}}\left(1.00 \mathrm{~J} \mathrm{~g}^{-1} \mathrm{~K}^{-1}\right)$, the transfer velocity $\mathrm{D}^{4}\left(1.59 \mathrm{~cm} \mathrm{~s}^{-1}\right.$, following Budyko, 1956, p. 46-57, and Sekioka and Yuhara, 1974, p. 2057), and the Bowen ratio $\mathrm{R}$ (Bowen, 1926) 0.3, determined for Mount Baker by calculating the ratio of heat loss from the surface by eddy diffusion and conduction to heat lost by evaporation in still air.

The present writers have made several modifications in the Sekioka and Yuhara (1974) model to reduce error in the geothermal-flux estimates. These modifications can be summarized as follows:

(1) An aerial infrared scanner has been used as the sensing system in preference to a land-based radiation thermometer to ensure virtual simultaneity in measurement.

(2) Atmospheric transmission-path corrections have been incorporated.

(3) A method has been introduced to assess the Bowen ratio.

(4) Local conditions at Mount Baker were taken into account in determining values for air density, vapor pressure, enthalpy of saturated water vapor, and the standard reference surface kinetic temperature.

(5) Estimates for advective heat loss via icemelt, fumarole emanations and vapor plumes, and meltwater drainage from the thermal area have been added to the heat budget of the ground surface.

\section{DIFFERENTIAL GEOTHERMAL FLUX FROM DORR FUMAROLE FIELD, 1972}

The subsurface temperature data (from depths of $15-100 \mathrm{~cm}$ ) obtained by DCP 6251 in 1972 and 1973 complement those data derived from density scans of the calibrated infrared images of November 20, 1972. Together, these data sets permit application of the empirical Dawson (1964) model for heat flow through soils that have heat-flux densities of less than $400 \mathrm{~W} \mathrm{~m}^{-2}$ and comparison of the Dawson model with the twopoint geothermal-flux model of Sekioka and Yuhara (1974).

An adaptation of the Dawson model (1964, p. 160) for calculation of convective heat flow $(\mathrm{H})$ to the surface from depth is given by

$$
\mathrm{H}=5.188 \mathrm{~T}_{15}{ }^{4} \times 10^{-6} \mathrm{~W} \mathrm{~m}^{-2}
$$

where $\mathrm{T}_{15}$ is the mean kinetic temperature $\left(\right.$ in $\left.{ }^{\circ} \mathrm{C}\right)$ at a depth of $15 \mathrm{~cm}$.

This relation was determined from temperature and heat-flow observations in the Wairakei area, New Zealand. The corresponding heat-flow relation between $\mathrm{T}_{100}$ and $\mathrm{T}_{15}$ has been established by Robertson and Dawson (1964).

The application of the Dawson model to DCP thermal probes 6,7 , and 8 in the Dorr Fumarole Field is given in table 2 (footnote 4 ).

The differential geothermal-flux densities generated by the Sekioka and Yuhara model for integrated kinetic temperature units of the Dorr Field are given in table 2 and are plotted against the differential radiant flux in figure 14 . The average flux density thus derived was $397 \mathrm{~W} \mathrm{~m}^{-2}$, compared to $287 \mathrm{~W} \mathrm{~m}^{-2}$ obtained by use of the Dawson model. The mean for the two models is $342 \mathrm{~W} \mathrm{~m}^{-2}$ and the mean standard deviation is $78 \mathrm{~W}$ $\mathrm{m}^{-2}$, which corresponds to a coefficient of variation of 23 percent.

\section{DIFFERENTIAL GEOTHERMAL FLUX FROM SHERMAN CRATER, 1972 AND 1975}

Table 2 contains figures for the differential geothermal flux from Sherman Crater on November 20, 1972, based on the heat balance of the ground surface estimated from density analysis of aerial infrared images and on our adaptation of the Sekioka and Yuhara (1974) model given in the previous section. This estimate excludes flux components from vapor plumes and fumarole emission to the atmosphere, ice melt, and other advective heat losses.

Also in table 2 is a similar differential geothermal flux estimate for the period following the increase in

TThe transfer velocity, $\mathrm{D}$, is the coefficient of diffusion of water vapor in the air. It is given

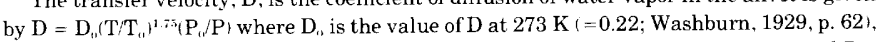
$\mathrm{T}$ is air temperature (in $\mathrm{K}), \mathrm{T}_{10}=273 \mathrm{~K}, \mathrm{P}$ is air pressure, and $\mathbf{P}_{4}=1$ atmosphere $(101.3 \mathrm{kPa}$ ) (Brunt, 1939, p. 421 ). 
thermal emission that began March 10, 1975. Integrated kinetic temperature zones are based on infrared images obtained by Rosenfeld $(1976,1977)$. This estimate excludes the same flux components left out of the 1972 estimate, and it also excludes heat lost from the central pit lake that developed in mid-1975. This heat loss is analyzed in the next section.

\section{HEAT LOSS FROM CENTRAL PIT LAKE, 1975}

After thermal activity increased in March 1975, a large ice pit developed near the center of Sherman Crater. The central pit was occupied by a warm lake, which had a surface area of $2,700 \mathrm{~m}^{2}$ by July of that year. Vertical ice walls rose about $40 \mathrm{~m}$ above the lake surface. The pit developed on the site of a saucershaped depression in the crater glacier, which had been noted in pre-1975 photographs and illustrated by Frank, Post, and Friedman (1975, p. 86, fig. 8), who speculated that a subglacial lake might exist under the crater glacier at that point. The water-equivalent thickness of the ice that melted out of the central pit is estimated at $25 \mathrm{~m}$. The near-surface kinetic temperature of the lake, $34^{\circ} \mathrm{C}$, was measured by thermometer on June 11, 1975. An infrared survey on June 30, 1975, reported by Eichelberger and others (1976, p. 42), gave a water-surface temperature range of $33-40^{\circ} \mathrm{C}$, but the average lake-surface temperature as estimated from this survey was approximately $33^{\circ} \mathrm{C}$ (J. E. Eichelberger, oral commun., June 1976). For the following heat-loss estimates, a mean surface kinetic temperature of $34^{\circ} \mathrm{C}$ was used.

The total nonadvective heat loss $\left(\mathrm{F}_{\mathrm{s}}\right)$ from a calm lake surface is given by the expression (Sutton, 1953)

$$
\mathrm{F}_{\mathrm{s}}=\mathrm{F}_{\mathrm{e}}(1+\mathrm{R})+\mathrm{F}_{\mathrm{b}},
$$

where the Bowen ratio, $\mathrm{R}=\mathrm{F}_{\mathrm{h}} / \mathrm{F}_{\mathrm{e}}$.

The synonymy and definition of terms used in this and the following subsections on heat loss from the central pit lake are as follows:

$F_{h}=$ net outgoing flux from the surface via eddy diffusion and molecular conduction

$\mathrm{F}_{\mathrm{b}}=$ differential radiant flux

$\mathrm{F}_{\mathrm{e}}=$ heat lost to the atmosphere by evaporation

$\mathrm{P}_{\mathrm{s}}=\mathrm{e}_{\mathrm{s}}=V=$ saturated pressure of water vapor [at $34^{\circ} \mathrm{C}$ in $\mathrm{mm} \mathrm{Hg}, \mathrm{P}_{\mathrm{s}}=39.898$ (Weast, 1970 , p. D143)]

$\mathrm{P}_{\mathrm{d}}=\mathrm{e}_{\mathrm{a}}=v=$ pressure of water vapor in atmosphere in $\mathrm{mm}$ of $\mathrm{Hg}$ [June 26,1975 , at $0^{\circ} \mathrm{C}, \mathrm{P}_{\mathrm{d}}=$ $4.579 \times 0.80$ (relative humidity) $=3.6632]$

$\mathrm{P}_{1}=$ atmospheric pressure in $\mathrm{mm}$ of $\mathrm{Hg}$ [at 3,000 $\mathrm{m}$ m.s.l. $=527.13$

$W=$ wind speed in $\mathrm{m} \cdot \mathrm{s}^{-1}[W=0$ to 1$]$
$\mathrm{T}_{\mathrm{s}}=$ temperature of water surface in ${ }^{\circ} \mathrm{C}[=34]$

$\mathrm{T}_{\mathrm{a}}=$ temperature of air in ${ }^{\circ} \mathrm{C}[=0]$

$\mathrm{M}=$ rate of evaporation in $\mathrm{kg} \mathrm{m}^{-2} \mathrm{hr}^{-1}$

In the following subsections, the $F_{\mathrm{e}}$ and $\mathrm{F}_{\mathrm{h}}$ components are estimated using two semiempirical equations (Washburn, 1929; and Robson and Willmore, 1955) based on evaporation-pan theory. (See table 4.) The overall heat loss from the lake surface estimated from equation 7 is then compared with that derived from equation 5 .

\section{EVAPORATION}

The $\mathrm{F}_{\mathrm{e}}$ component in equation 7 can be estimated using the following relationship (Washburn, 1929, p. 54, and Dawson, 1964, p. 162):

$$
\mathrm{M}=(0.031+0.0135 W)\left(\mathrm{P}_{\mathrm{s}}-\mathrm{P}_{\mathrm{d}}\right)\left(760 / \mathrm{P}_{1}\right) .
$$

Where $W=0, \mathrm{M}=1.6195 \mathrm{~kg} \mathrm{~m}^{-2} \mathrm{hr}^{-1}$. Since the area of the lake is $2,700 \mathrm{~m}^{2}$, and the enthalpy of water vapor at $34^{\circ} \mathrm{C}=622.3 \mathrm{cal} \mathrm{g}^{-1}$,

$$
\mathrm{F}_{\mathrm{e}}=3.2 \times 10^{6} \mathrm{~W} \text {. }
$$

Where $W=1 \mathrm{~m} \mathrm{~s}^{-1}, \mathrm{M}=2.3248 \mathrm{~kg} \mathrm{~m}^{-2} \mathrm{hr}^{-1}$, and

$$
\mathrm{F}_{\mathrm{e}}=4.5 \times 10^{6} \mathrm{~W} \text {. }
$$

An alternative equation for calculation of evaporation from a heated water surface is given by Robson and Willmore (1955, p. 21):

TABLE 4.-Anomalous nonadvective heat flux from Sherman Crater in 1972 and 1975, including calculations for central pit lake based

\begin{tabular}{|c|c|c|}
\hline Component & 1972 & 1975 \\
\hline $\begin{array}{l}\text { Anomalous heat flux, exclusive of } \\
\text { central pit lake } \\
\text { (from table 2)----- }\end{array}$ & $3.6 \mathrm{MW}$ & $10.6 \mathrm{MW}$ \\
\hline \multicolumn{3}{|l|}{ Centra1 pit lake: } \\
\hline $\begin{array}{l}\text { table } 2)- \\
\text { Nonradiant transfer (where } \mathrm{W}=0 \text { ): }\end{array}$ & 0 & $.6 \mathrm{MW}$ \\
\hline Evaporation---_. & 0 & $=1.8-3.2 \mathrm{MW}$ \\
\hline Conduction and diffusion--------- & 0 & $20.8-1.0 \mathrm{MW}$ \\
\hline Total for lake---- & 0 & $3.2-4.7 \mathrm{MW}$ \\
\hline Total anomalous heat flux from crater-- & $3.6 \mathrm{MW}$ & $13.8-15.4 \mathrm{MW}$ \\
\hline \multicolumn{3}{|l|}{ Mean nonadvective heat-flux density: } \\
\hline In thermal areas--- & $410 \mathrm{~W} \mathrm{~m}^{-2}$ & $395-472 \mathrm{~W} \mathrm{~m}^{-2}$ \\
\hline $\begin{array}{l}\text { Averaged over entire Sherman Crater } \\
\left(167,000 \mathrm{~m}^{\prime}\right)\end{array}$ & $22 \mathrm{~W} \mathrm{~m}^{-2}$ & $79-95 \mathrm{w} \mathrm{m}^{-2}$ \\
\hline
\end{tabular}
on two different models

[Excludes plume, icemelt, and other advective heat loss. Area of lake, $2,700 \mathrm{~m}^{2}$; emissivity, 0.99 ; lake temperature, $34^{\circ} \mathrm{C}$ (as measured by Frank, June 11, 1975)]

${ }^{1}$ Lake was not present in 1972.

-Lower estimate was calculated using model of Robson and Willmore (1955); higher estimate was derived from model of Sutton. (1953) and Dawson (1964). Figure shown in table 3 for total heat flux from lake $(2.0 \mathrm{MW}$ ) was derived from model of Sekioka and Yuhara (1974). 
$\mathrm{F}_{\mathrm{e}}=(1+\mathrm{T} / 150)(1+0.33 W)(V-v)$

$$
\times 0.33 \times 10^{-3} \mathrm{cal} \mathrm{cm}^{-2} \mathrm{~s}^{-1} \text {. }
$$

Where $W=0, \mathrm{~F}_{\mathrm{e}}=1.7 \times 10^{6} \mathrm{~W}$; where $W=1, \mathrm{~F}_{\mathrm{e}}=2.3$ $\times 10^{6} \mathrm{~W}$.

These alternative semiempirical methods thus yield results that differ by 25 percent, which is less than the combined probable error in the overall estimate. Evaporative heat loss from the central pit lake surface is plotted in figure 16 as a function of temperature and windspeed for prevailing conditions at Sherman Crater.

\section{CONDUCTION AND DIFFUSION TO ATMOSPHERE}

Bowen (1926, p. 779), following the work of Ångström (1920) and others, showed that the process of evaporation and diffusion of water vapor $\left(\mathrm{F}_{\mathrm{e}}\right)$ from any water surface into the body of air above it replicates that of the conduction or diffusion of specific heat energy $\left(F_{h}\right)$ from the water surface into the same body of air. Because of this relationship, it is possible to represent the heat loss by conduction and turbulence to that by evaporation by a specified ratio, $\mathrm{R}$, which Bowen introduced, in which $R=F_{h} / F_{e}$. By considering limit- ing atmospheric conditions, Bowen arrived at the expression

$$
\mathrm{R}=6.1 \times 10^{-4} \mathrm{P}_{1}\left(\mathrm{~T}_{\mathrm{s}}-\mathrm{T}_{\mathrm{a}}\right)\left(\mathrm{e}_{\mathrm{s}}-\mathrm{e}_{\mathrm{a}}\right)^{1 / 2} .
$$

Bowen's limiting conditions assume molecular diffusion and conduction and therefore apply only to laminar motion, but Bowen inferred that the ratio of heat losses would be much the same in turbulent motion (Sutton, 1953, p. 314-315). Bowen's inference was investigated by Cummings and Richardson, who found that Bowen's theoretical conclusions were supported by their own empirical observations. Cummings and Richardson conclude (1927, p. 534) that it is worthwhile to assess the value of $R$ at various places and various times of the year. Substituting the variables listed above into equation $10, \mathrm{R}=0.30$ for the central pit lake in Sherman Crater in July 1975. And since $F_{e}$ ranges from $3.2 \times 10^{6}$ to $4.5 \times 10^{6} \mathrm{~W}$, as shown by equation $9, \mathrm{~F}_{\mathrm{h}}$ would range from $1.0 \times 10^{6}$ to $1.4 \times 10^{6}$ W.

An alternate expression for heat flow from a surface into a convecting vapor is given by Robson and Willmore (1955, p. 21):

$\mathrm{F}_{\mathrm{h}}=(1+.0069 \Delta \mathrm{t}) \times 2.04 \times 10^{-4} \mathrm{cal} \mathrm{cm}^{-2} \mathrm{~s}^{-1}$, where $\Delta \mathrm{t}$ is the difference in ${ }^{\circ} \mathrm{C}$ between the surface

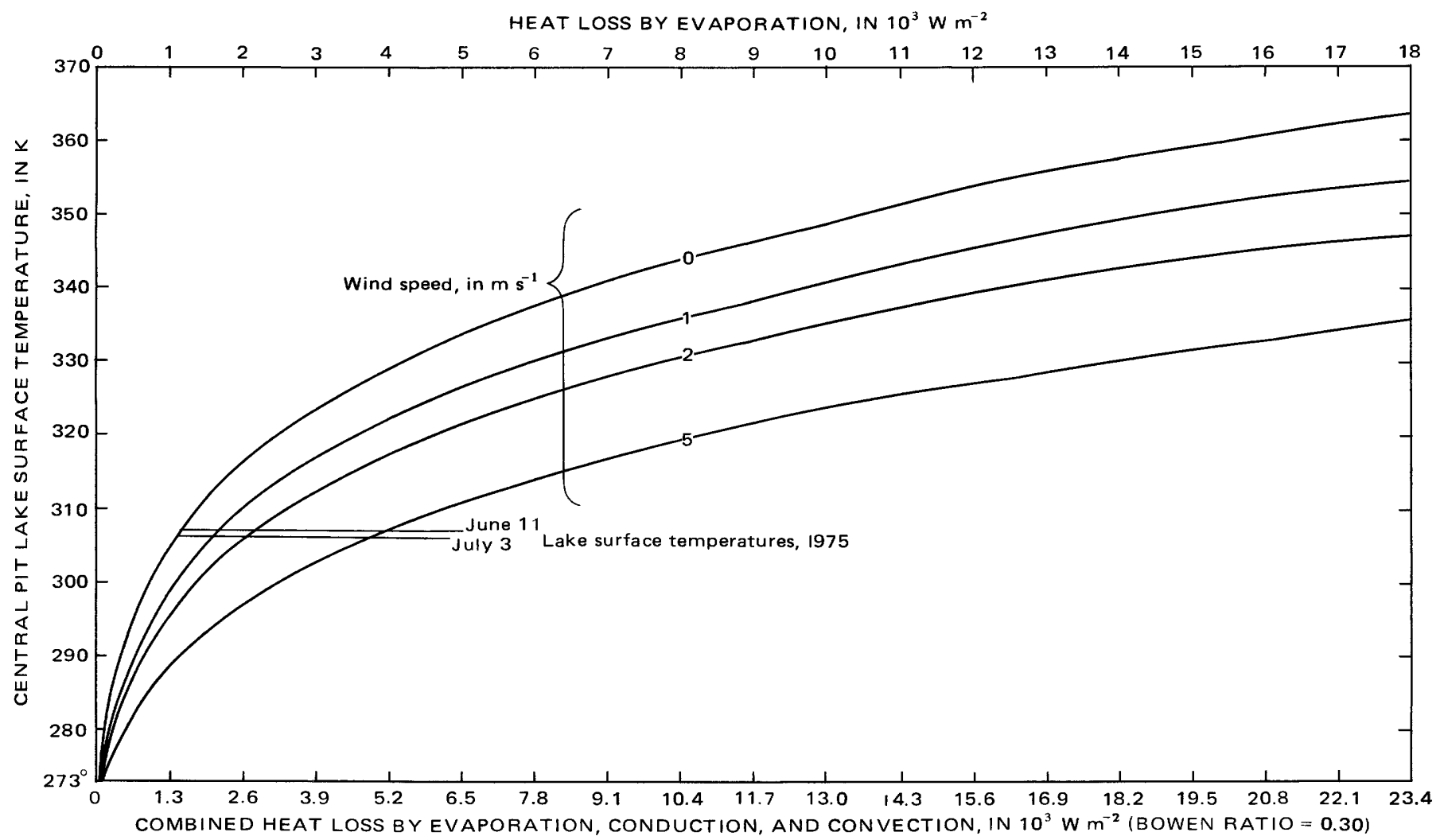

FIGURE 16.-Evaporative heat loss from the surface of the central pit lake, Sherman Crater, as a function of kinetic water-surface temperature and windspeed, at $273 \mathrm{~K}$ air temperature. 
and the atmosphere $\left(\mathrm{T}_{\mathrm{S}}-\mathrm{T}_{\mathrm{a}}\right)$. Substituting the variables listed above $\mathrm{F}_{\mathrm{h}}=292 \mathrm{~W} \mathrm{~m}^{-2}$ or $0.8 \times 10^{6} \mathrm{~W}$.

\section{RADIANT HEAT LOSS}

The net radiant loss to the atmosphere is estimated from equation 1 and the area of the lake where

$$
\begin{gathered}
\mathrm{T}_{1}=34^{\circ} \mathrm{C} \text {, the main temperature of the } \\
\quad \text { lake surface, } \\
\mathrm{T}_{2}=0^{\circ} \mathrm{C} \text {, the adjacent, nonanomalously } \\
\quad \text { warm ground surface, }
\end{gathered}
$$

and

$$
\begin{aligned}
\epsilon & =0.99 \pm 0.01 \\
\mathrm{~F}_{\mathrm{b}} & =186 \mathrm{~W} \mathrm{~m}^{-2} \text { or } 0.50 \times 10^{6} \mathrm{~W} .
\end{aligned}
$$

\section{TOTAL HEAT LOSS}

If the values for $F_{e}, R$, and $F_{b}$ from the foregoing analysis are substituted into equation $7, \mathrm{~F}_{\mathrm{s}}=1700$ to $2370 \mathrm{~W} \cdot \mathrm{m}^{-2}$, or $4.6 \times 10^{6}$ to $6.4 \times 10^{6} \mathrm{~W}$. This range in values reflects the variation in wind speed and the differing values for $\mathrm{F}_{\mathrm{e}}$ obtained from equations 8 and 9 .

$$
\text { DIFFERENTIAL GEOTHERMAL FLUX AND COMPARISON OF }
$$

$$
\text { HEAT-LOSS ESTIMATES }
$$

Total heat loss from the lake surface can also be approximated using equation 5 and the area of the lake, from which the differential geothermal flux, $\Delta \mathrm{G}=745$ $\mathrm{W} \mathrm{\textrm {m } ^ { - 2 }}$ for a total heat loss of $2.0 \times 10^{6} \mathrm{~W}$.

Deviations from mean heat-flow estimates were calculated for the central pit lake, where three heatbalance models were applied. Heat-flow estimates for the central pit lake ranged from $2.0 \times 10^{6}$ to $4.6 \times 10^{6}$ $\mathrm{W}$ (table 6 ). The mean is $3.2 \pm 1.4 \times 10^{6}$, equivalent to a coefficient of variation of 57 percent.

Equation 7, as applied here, yields a Bowen ratio $\left(\mathrm{F}_{\mathrm{l}} / \mathrm{F}_{\mathrm{e}}\right), \mathrm{R},=0.30$; application of the Robson-Willmore model yields $R=0.31$.

HEAT EXCHANGE VIA MASS TRANSFER FROM FUMAROLES, 1975

With the exception of data on temperature variations, little quantitative information is available on fumarole emanations from Sherman Crater for the 1972-73 period. Fumaroles of the Dorr Field, monitored by the DCP system, averaged $90.8^{\circ} \mathrm{C}$ in 1973 (table 3). In March 1975, however, Kiver and Steele (1976) measured the velocities of fumarole gases in the west-rim sector of Sherman Crater and along the edge of the newly formed crater lake in the central pit. The much larger fumaroles in the east-breach sector were not measured. The volumetric rate of fumarolic gas emission reported by Kiver and Steele (1976) was 0.35 $\mathrm{m}^{3} \mathrm{~s}^{-1}$, somewhat less than 1 percent of the total from Sherman Crater at that time (E. P. Kiver, oral commun., July 21, 1976). We infer here, based on field reconnaissance, that fumarolic gas emission of $0.35 \mathrm{~m}^{3}$ $\mathrm{s}^{-1}$ is approximately 1 percent of the total gas emission at $90^{\circ} \mathrm{C}$.

The heat lost to the atmosphere via mass transfer $\left(Q_{1}\right)$ from fumarolic vapor emission in Sherman Crater (neglecting nonaqueous constituents of the vapor) can be estimated by using an expression of the form

$$
\mathrm{Q}_{1}=\mathrm{vf} \rho H,
$$

where $\mathrm{v}=$ volumetric rate of transfer of fumarole vapor ( $=0.35 \mathrm{~m}^{3} \mathrm{~s}^{-1}$ for 1 percent of the fumaroles), $\mathrm{f}=$ relative humidity of the ascending vapor $(=0.95), \rho=$ density of saturated water vapor at $90^{\circ} \mathrm{C}(=0.428 \times$ $10^{-3} \mathrm{~g} \mathrm{~cm}^{-3}$; Perry and others, 1969, p. 3-191), $H=$ enthalpy of saturated water vapor at $90^{\circ} \mathrm{C}$ and barometric pressure equivalent to $3,000 \mathrm{~m}$ m.s.l. (= $630.4 \mathrm{cal} \mathrm{g}^{-1}$; Keenan and Keyes, 1936; Burnham and others, 1969, p. 14). From equation $12, Q_{1}=0.37 \times 10^{6}$ $\mathrm{W}$ for the fumaroles investigated by Kiver and Steele. For the entire Sherman Crater, heat lost via mass transfer from all fumaroles in March 1975 would then have been about $37 \times 10^{6} \mathrm{~W}$. However, the uncertainty in this value is estimated at 100 percent.

\section{ADVECTIVE HEAT LOSS VIA MELT-WATER DRAINAGE, 1972 AND 1976}

The volumetric outflow of the melt-water stream (Crater Creek) draining the entire Sherman Crater was estimated on July 14, 1976, by Frank to be $0.2 \mathrm{~m}^{3}$ $\mathrm{s}^{-1}$. The water temperature was $22^{\circ} \mathrm{C}$. The estimated advective heat loss by snowmelt and icemelt given by Frank, Meier, and Swanson (1977, p. 17) and shown in revised form in table 5 does not include the heat content of melt water above $0^{\circ} \mathrm{C}$. The enthalpy of water at $22^{\circ} \mathrm{C}$ and $3,000 \mathrm{~m} \mathrm{~m} . \mathrm{s} .1$. is $91.62 \mathrm{~J} \mathrm{~g}^{-1}$, hence the heat content of the melt-water stream is $\sim 18 \times 10^{6} \mathrm{~W}$.

The estimated outflow in 1972 was $0.1 \mathrm{~m}^{3} \mathrm{~s}^{-1}$ at 7 to $8^{\circ} \mathrm{C}$ (as measured by Frank), equivalent to an advective heat loss of $3 \times 10^{6} \mathrm{~W}$.

\section{ANALYSIS OF PROPAGATION OF ERROR IN FLUX CALCULATIONS}

Table 6 gives the estimated mean standard deviation and variance for significant independent variables for four categories of flux calculations reported in this paper: differential radiant flux density $\left(F_{b}\right)$, outgoing net flux to the atmosphere by diffusion and conduction $\left(\mathrm{F}_{\mathrm{h}}\right)$, outgoing flux to the atmosphere via evaporation $\left(\mathrm{F}_{\mathrm{e}}\right)$, and rate of advective heat loss via mass transfer 
TABLE 5.-Estimated total heat discharge from Sherman Crater, Mount Baker, Washington, 1972 and 1975, from all major sources

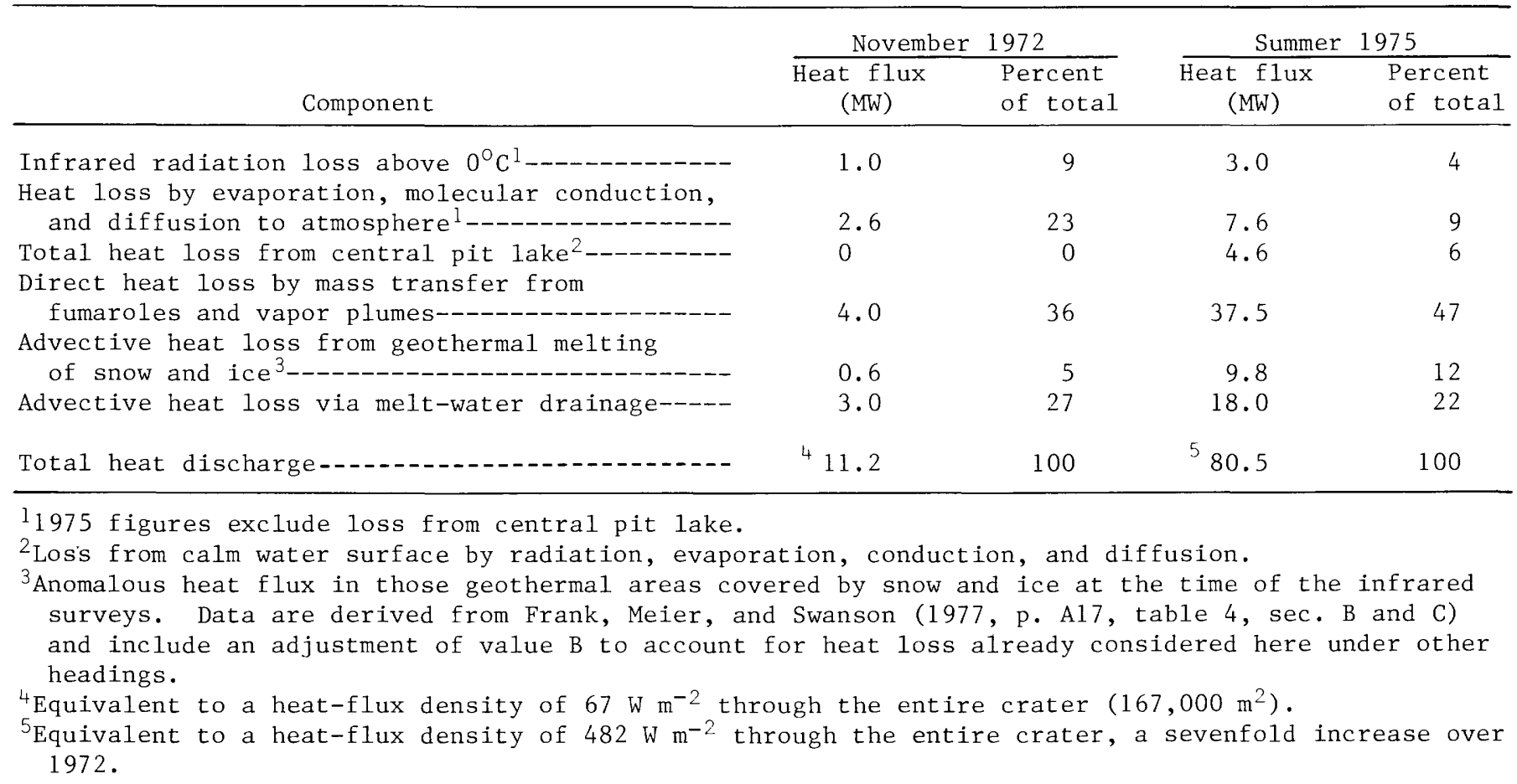

from fumaroles $\left(\mathrm{F}_{\mathrm{ad}}\right)$. From these estimates, the propagation of error in flux calculations for the major components of power output is analyzed (table 7) using the method of Bevington (1969, p. 56-65). Percentages of error accumulated in calculating $F_{h}, F_{h}, F_{e}, F_{a d}$ (fumaroles only), and $\Delta \mathrm{G}$ (differential geothermal flux using the Sekioka and Yuhara model) are tabulated. The combined error for overall power output for the two basic models tested in this investigation, $\mathrm{Q}_{\mathrm{a}}=$ $\mathrm{F}_{\mathrm{b}}+\mathrm{F}_{\mathrm{h}}+\mathrm{F}_{\mathrm{e}}+\mathrm{F}_{\mathrm{ad}}$ (eq. 4) and $\mathrm{Q}_{\mathrm{b}}=\Delta \mathrm{G}+\mathrm{F}_{\mathrm{ad}}$ (eqs. 5 and 12 ), is also given. The lower combined error was obtained using the Sekioka and Yuhara model $\left(Q_{\mathrm{b}}\right)$ and is 55 percent. The largest uncertainty, the volumetric rate of transfer of fumarole vapor $\left(\mathrm{F}_{\mathrm{ad}}\right)$, is inherent in $\mathrm{Q}_{\mathrm{a}}$ and $\mathrm{Q}_{\mathrm{b}}$ models. If $\mathrm{F}_{\mathrm{ad}}$ were known at 50 percent error, the overall error in $Q_{b}$ would be only 29 percent.

\section{HEAT-FLLX SLMMARY}

The estimated heat discharge and energy partition at Sherman Crater in November 1972 is compared to that of 1975 in table 5. In terms of energy partition, heat loss from Mount Baker was dominated, both before and after the thermal event of 1975 , by mass transfer from fumaroles, which increased in significance in 1975. The second largest mode of heat transfer in 1972 was advection through melt-water drainage, and it remained so in 1975. Although all modes of heat transfer increased in 1975, the percentage of loss by evaporation, diffusion, and conduction to the atmosphere declined to fourth most important. Radiation loss, although increasing quantitatively, declined in percentage of total heat loss between 1972 and 1975.

\section{INFERRED ENERGY YIELD DURING REPOSE}

The 1972 heat-flux density in Sherman Crater (table 5 , footnote 4) is estimated at $67 \pm 37 \mathrm{~W} \mathrm{~m}^{-2}$ for the entire crater, compared to a heat-flux density of $20 \mathrm{~W}$ $\mathrm{m}^{-2}$ for thermal areas in the vast Torfajökull silicic volcanic center (Pálmason and others, 1970) of Iceland (table 8), based on Böðvarsson (1961), and 45-50 W $\mathrm{m}_{-2}$ for thermal zones in the Grímsvötn caldera in the ice sheet Vatnajökull (Björnsson, 1974, p. 18). From a review of historical data and photographs of thermal ground and fumaroles, we infer that the 1972 energy yield of Sherman Crater represents a maximum of near-steady-state conditions that prevailed for the past century. The average energy yield would then have been somewhat less than $11.2 \pm 6.2 \mathrm{MW}$ or $3.5 \pm 1.9 \times$ $10^{14} \mathrm{~J} \mathrm{yr}^{-1}$.

\section{COMPARISON BETWEEN 1972 ENERGY YIELD AND 1975 ENERGY YIELD}

The total heat discharge from Sherman Crater increased in 1975 to about $80.5 \pm 44.3 \mathrm{MW}$ (about $2.5 \pm 1.4$ 


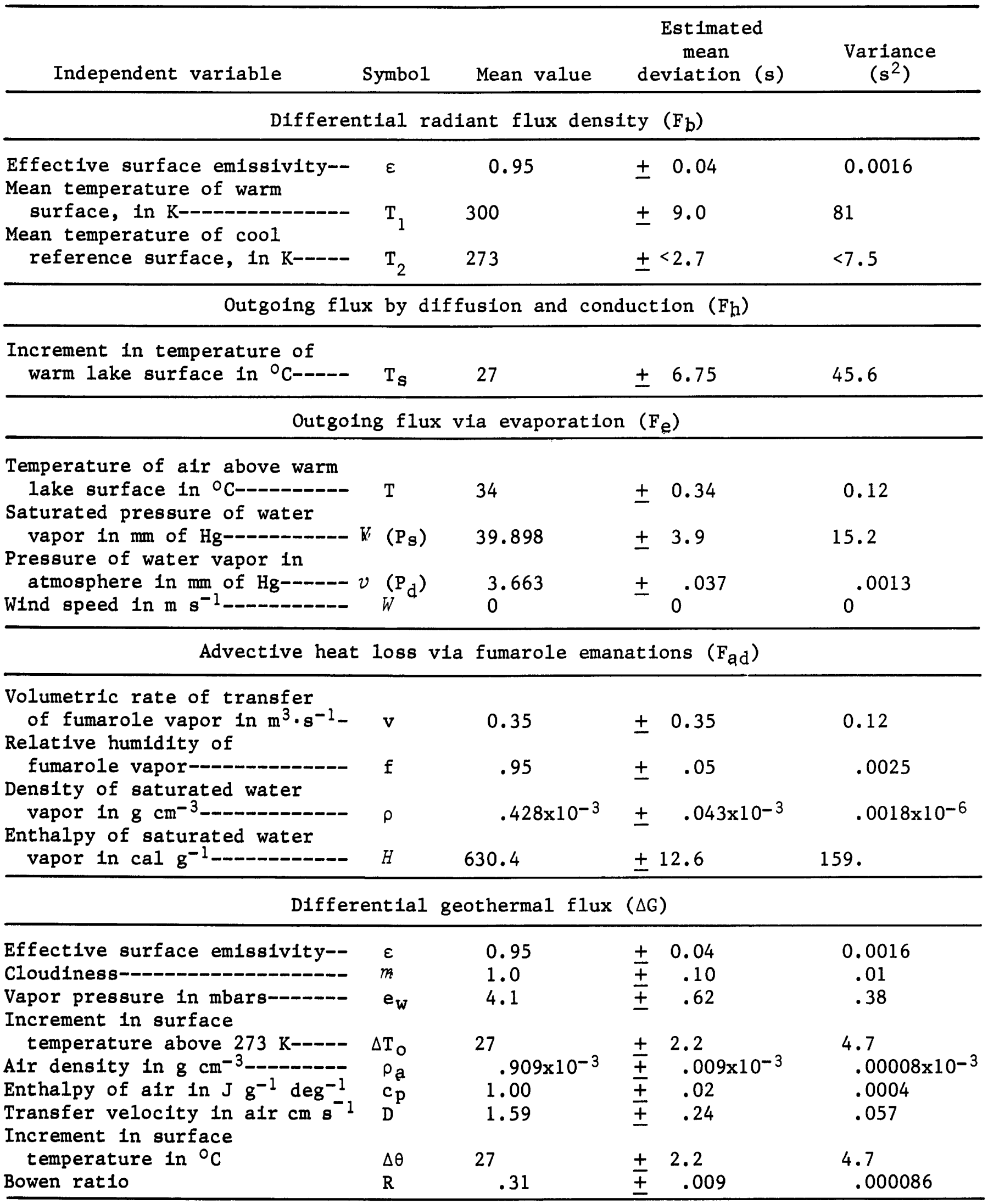


TABLE 7.-Analysis of propagation of error in flux calculations

[Following the method of Bevington (1969, p. 56-65) and assuming that variables are independent and not correlated]

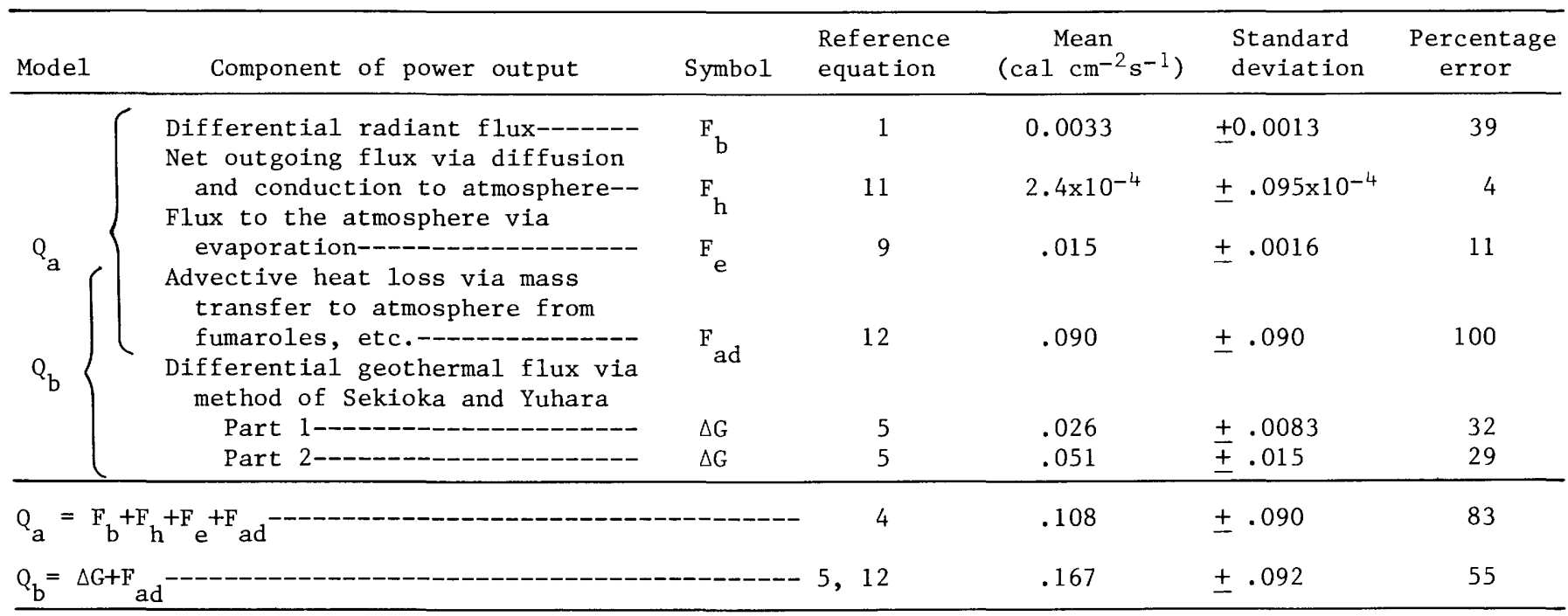

TABLE 8.-Comparative energy yield of selected volcanoes and geothermal areas

[.... indicates no data available]

\begin{tabular}{|c|c|c|c|c|c|c|}
\hline $\begin{array}{l}\text { Volcano or } \\
\text { geothermal area }\end{array}$ & \multicolumn{2}{|c|}{$\begin{array}{l}\text { Surface thermal } \\
\text { manifestations }\end{array}$} & $\begin{array}{l}\text { Equivalent } \\
\text { 100-yr rate } \\
\text { of energy } \\
\text { release } \\
\left(x 10^{18} \mathrm{~J}\right)\end{array}$ & \multicolumn{2}{|c|}{$\begin{array}{l}\text { Anomalous } \\
\text { geotherma1 } \\
\text { flux over } \\
\text { assumed } 400-\mathrm{km}^{2} \\
\text { volcanic domain } \\
\left(\mathrm{W} \mathrm{\textrm {m } ^ { - 2 } )} \frac{(\mathrm{hfu})}{}\right.\end{array}$} & Reference \\
\hline \multicolumn{7}{|l|}{ Kilauea-Mauna Loa, } \\
\hline Grímsvötn, Iceland ${ }^{1},{ }^{2}-$ & 100 & 47.5 & 15 & 12 & 285 & Björnsson (1974, p. 18). \\
\hline $\begin{array}{c}\text { Nyiragongo, Zaire------ } \\
\text {... }\end{array}$ & .13 & 300,000 & 13 & 10.5 & 250 & $\begin{array}{l}\text { Bonnet }(1960, \text { p. 713); Delsemme } \\
\quad(1960 \text {, p. 705-6). }\end{array}$ \\
\hline Torfajökull, Iceland ${ }^{2}-$ & 100 & 20 & 6.5 & 5 & 120 & Björnsson (1974, p. 17). \\
\hline Kverkfjö11, Iceland ${ }^{2}--$ & --- & --- & $>4$ & $>3$ & $>90$ & $\begin{array}{l}\text { Friedman and others (1972, } \\
\text { p. 40-41). }\end{array}$ \\
\hline Hekla, Iceland ${ }^{1}-------$ & --- & -- & 3 & 2.5 & 60 & Friedman and others (1970). \\
\hline Vesuvius, Italyl------ & --- & --- & 1 & .8 & 20 & Yokoyama (1972, p. 167). \\
\hline Oshima, Japan ${ }^{1}--------$ & -- & $-\cdots$ & .6 & .5 & 12 & Yokoyama (1972, p. 166). \\
\hline $\begin{array}{l}\text { Tikitere, New Zealand }{ }^{2} \\
\text { Mount Baker, }\end{array}$ & .25 & 485 & .4 & .3 & 7 & Dickinson, 1973, p. 1). \\
\hline $\begin{array}{l}\text { Washington, 1975---- } \\
\text { Mount Baker, }\end{array}$ & .17 & 482 & 3.25 & .20 & 4.6 & This report. \\
\hline Washington, 1972---- & .17 & 67 & 3.04 & .03 & .8 & This report. \\
\hline
\end{tabular}

${ }^{1}$ Volcanoes for which steady-state energy yields are inferred.

${ }^{2}$ Geothermal field for which steady-state heat flows are inferred.

${ }^{3}$ Projected to 100-year rate for comparative purposes only.

$\times 10^{15} \mathrm{~J} \mathrm{yr}^{-1}$ ) from $11.2 \pm 6.2 \mathrm{MW}$ in 1972 . Thus, the heat-flux density averaged over the entire Sherman Crater increased from about $67 \pm 37 \mathrm{~W} \mathrm{~m}^{-2}$ in 1972 to about $482 \pm 265 \mathrm{~W} \mathrm{~m}^{-2}$ in 1975 .
The thermal-balance method used to arrive at these conclusions is essentially different from the method used by Frank, Meier, and Swanson (1977) to make their icemelt heat-flow estimate. The two results are 
not strictly comparable because a wider, more comprehensive range of heat-loss mechanisms was considered in the thermal-balance method and because the icemelt estimate averages heat flow over long periods. Yet even with the sparse data available on critical components such as mass transfer from fumaroles, the thermal-balance method yielded estimates suggesting an increase in heat flow in 1975 of about the same order of magnitude as that shown by the snow-andice-melt method. For that part of the total heat flow that could account for the observed snow and ice loss, Frank, Meier, and Swanson (1977, p. A16) calculated a heat-flux change from $2 \mathrm{MW}$ to about $30 \mathrm{MW}$ during 1975 , or an increase factor of about 15 . The thermalbalance method in the present report yielded an overall heat-flux change from $11 \mathrm{MW}$ in 1972 to $80 \mathrm{MW}$ in 1975 , an increase factor of about 7 , after including that part of the snow-and-ice-melt estimates that is not duplicated by the present methods (table 5). It is not surprising that a greater part of the total heat flow should go into melting snow and ice in 1975, considering that much of the new thermal activity had a subglacial origin.

\section{DISCUSSION}

$\mathrm{F}_{\mathrm{b}} / \mathrm{F}_{\mathrm{s}}$ ratios obtained for the central pit lake, the Dorr Fumarole Field, and the entire Sherman Crater by application of the three heat-balance models in the preceding sections range from 0.11 to 0.28 ; the mean $F_{b} / F_{s}$, $0.21 \pm 0.09$, is close to that obtained $(0.24 \pm 0.02)$ using the Sekioka-Yuhara model alone.

If we examine the literature for the relationship between radiant and total heat loss from volcanic and geothermal manifestations, two examples may be readily cited: (1) Decker and Peck (1967, p. D175) found that at the crustified Alae lava lake, Hawaii, the net radiant heat loss was 10 percent of the total heat loss, and (2) Friedman and others (1969) calculated that at Surtsey, Iceland, radiant heat loss (as detected by the Nimbus 2 high-resolution infrared radiometer) from an incandescent lava eruption in 1966 was 3.4 percent of the total volcanogenic heat loss. Comparable estimates from the present experiment indicate the differential radiant flux was 8.9 percent of the total volcanogenic flux $\left(\mathrm{F}_{\mathrm{b}} / \mathrm{Q}\right)$ at Mount Baker in 1972 and 3.7 percent in 1975.

If the 1972 energy transfer from the Sherman Crater represents a maximum of near-quiescent conditions, as suggested by the historical evidence presented and analyzed in previous sections, the sevenfold increase in energy transfer that began in March 1975 and continued through 1976 requires a specific geologic explanation rooted in a process or event.
Tiltmeter and seismic records are not adequate for the period before 1975 (because of the lack of instrument stations) to establish the nature of the event or process that culminated in the increase in thermal emission on about March 10, 1975. Subsequent tiltmeter and seismic records show virtually no evidence for magma movement or infusion since March 10, 1975, along conduits beneath Sherman Crater.

The net increase in energy yield from 1972 to 1975 (80.5 MW - 11.2 MW $=69.3 \mathrm{MW})$ is equivalent to $2.2 \pm 1.2 \times 10^{15} \mathrm{~J} \mathrm{yr}^{-1}$. The rate of energy transfer in 1976 remained at about the same level. Without endorsing a magmatic hypothesis, we may estimate the mass-transfer equivalent of volcanic energy yield in the manner of Yokoyama (1972, p. 165), Swanson, Wright, and Helz (1975, p. 900), and Blackwell (1978, p. 182), who have shown that volcanic thermal energy yield, based on the specific and latent heat content of lava and assuming cooling of an effusive lava to ambient temperature levels, ranges between 1,360 and $1,507 \mathrm{~J} \mathrm{~g}^{-1}$. Thus, the net increase in thermal energy yield at Sherman Crater in 1975 would correspond to a magma mass of $1.6 \pm 0.8 \times 10^{9} \mathrm{~kg}$ (about $0.62 \times 10^{6} \mathrm{~m}^{3}$ ).

A larger mass of magma would be required to account for the energy output of Mount Baker if devolatilization of magma occurred at depth. Assuming that 5 percent of the mass of a magma body was transported to the surface in the form of hydrothermal vapor, we can estimate the magnitude of the hypothetical body from the energy output of the system.

If we assume an enthalpy of $2,680 \mathrm{~J} \mathrm{~g}^{-1}$, which would reflect the temperature and pressure conditions at the surface at Sherman Crater, the hydrothermal vapor equivalent of the annual heat discharge at Sherman Crater in 1975 and 1976 would be $9 \pm 5 \times 10^{8} \mathrm{~kg} \mathrm{yr}^{-1}$, equivalent to the devolatilization of $2 \pm 1 \times 10^{10} . \mathrm{kg}$ of magma per year. The volume of magma involved would be $0.008 \mathrm{~km}^{3}$, or, in the most compact form, a sphere of $124 \mathrm{~m}$ radius. Interestingly, Frank, Meier, and Swanson (1977, p. A17) found that the surface distribution of hydrothermal activity in Sherman Crater can be summarized as having a central core of heat emission $60-80 \mathrm{~m}$ in diameter, near the east breach, on which is superposed a semicircular zone of activity $400 \mathrm{~m}$ in diameter, along the inside crater rim.

Although an increase in activity in the Mount Baker hydrothermal system might be associated with the devolatilization or cooling of a small magma body at depth, the sevenfold increase in fumarolic activity in 1975 at Sherman Crater could as well be accounted for by an influx and subsequent loss of high-temperature fluids as the result of an independent abyssal process. The lack of direct geophysical evidence for the intrusion or devolatilization of a magma body or chamber in 
the conduit system beneath Sherman Crater suggests that a nonmagmatic hypothesis would be better. It is not unusual for energy yields of the magnitude reported here for Mount Baker to occur during repose or dormant periods of a volcanic system. In this connection, we note that more than 34 percent of the total energy release in Quaternary time in the Kamchatka volcanic province (Polak, 1967, p. 136) has occurred as a result of fumarolic activity at individual volcanoes during dormant periods rather than during eruptions.

Moreover, the level of energy output from Mount Baker, even after the increase of 1975 , suggests that in heat-flux density and rate of energy release, the Mount Baker system more closely resembles a small hydrothermal field of the Tikitere, New Zealand, type (table 8) than the moderate to large geothermal fields associated with volcanic systems like Nyiragongo, Zaire, or Kilauea-Mauna Loa, Hawaii, where the high-level energy yield can be attributed to recurrent influx of magma into the volcanic system.

Thus, the heat-flow evidence at hand establishes the magnitude of the 1975 thermal event at Mount Baker, but is not yet adequate to demonstrate conclusively whether the additional supply of heat can be attributed to devolatilization of a magma body or, more likely, to influx of high-temperature fluids from depth.

\section{SUMMARY AND CONCLUSIONS}

(1) Seven aerial infrared scanner missions were flown over Mount Baker, Wash., between 1970 and 1973 , including one survey on November 20,1972 , in which an RS-14 scanner produced calibrated, taped infrared images. Data from these missions were used to reconstruct the 1972 surface thermal regime of Sherman Crater and the Dorr Fumarole Field of Mount Baker by mapping radiometric surface temperatures of anomalously warm zones associated with ice perforations and fumarole clusters. An assessment of Mount Baker's heat exchange with the atmosphere before and after the March 1975 increase in thermal emission was built up from the surface thermal regime.

(2) The scanner temperature readout was corrected for atmospheric attenuation due to $\mathrm{H}_{2} \mathrm{O}$ and $\mathrm{CO}_{2}$ along the transmission path by use of radiosonde data, standard model atmospheres, and transmissivity curves for the 8-14 $\mu \mathrm{m}$ region.

(3) A planimetrically corrected map plot of radiometric surface-temperature zones was derived from a film readout of the scanner tapes via imagedensity slicing using an emulsion-density scanning microscope.
(4) Ground kinetic temperature units were established for the anomalous zones by applying surface emissivity corrections to the radiometric temperature map plot.

(5) A two-point differential radiant-flux (or radiant-exitance) model, based on the StefanBoltzmann function, provided an estimate of radiantflux density for each kinetic temperature unit in relation to a selected reference surface at $273 \mathrm{~K}$.

(6) A two-point model (requiring synchronous surface-temperature records) for heat balance of the ground surface was modified by the writers for use with temperature data derived from synoptic aerial infrared scanner images under conditions prevailing at Mount Baker. In addition to the corrections listed above, evaporation from the warm crater-lake surface was estimated independently using evaporation-pan theory, and the Bowen ratio $(R=\sim 0.3)$ was calculated and used to derive heat loss to the atmosphere via diffusion and conduction from the figures for evaporation. The differential geothermal flux was then calculated in relation to the 273-K reference surface.

(7) An electronic thermal sensor system integrated with a Landsat data collection platform provided repetitive near-surface $(30-50 \mathrm{~cm})$, surface, fumarole-vapor, and ambient-air temperatures over a period of several months in 1973 and 1974 for a site within the Dorr Fumarole Field, yielding data for an independent estimate of near-surface flux density.

(8) The differential radiant flux from Sherman Crater for the 1972 period was estimated at $1.0 \pm 0.4$ MW and the total heat discharge at $11.2 \pm 6.2 \mathrm{MW}$ including advective heat loss from icemelt and surface drainage and direct heat loss via mass transfer from fumarole emanations.

(9) Application of the same procedure to infrared scanner images made in 1975 indicated a differential radiant flux of $3.0 \pm 1.6 \mathrm{MW}$ and a total heat discharge (as defined above) of $80.5 \pm 44.3 \mathrm{MW}$.

(10) The annual energy yield from Sherman Crater in 1972 was estimated as $3.5 \pm 1.9 \times 10^{14} \mathrm{~J} \mathrm{yr}^{-1}$ and in 1975 as $2.5 \pm 1.4 \times 10^{15} \mathrm{~J} \mathrm{yr}^{-1}$. A sevenfold increase in heat discharge was thus associated with the thermal events that began in March 1975.

(11) The hydrothermal vapor equivalent of the annual heat discharge would be $9.0 \pm 5.0 \times 10^{8} \mathrm{~kg} \mathrm{yr}^{-1}$ at an enthalpy of $2,680 \mathrm{~J} \mathrm{~g}^{-1}$. Although there is no independent evidence of emplacement of a magma body in the conduit system beneath Sherman Crater, the annual level of hydrothermal emission would be equivalent to the devolatilization of $2.0 \pm 1.0 \times 10^{10} \mathrm{~kg}$ of magma per year at depth, or to the influx and subsequent loss of equivalent hydrothermal fluids as the result of an independent abyssal process. 


\section{REFERENCES CITED}

Ångström, Anders, 1920, Application of heat radiation measurements to the problems of evaporation from lakes and the heat convection at their surfaces: Geog. Annaler, v. 2, p. 237-252.

1925 , On radiation and climate: Geog. Annaler, v. 8, p. $122-142$.

Banwell, C. J., 1970, Geophysical techniques in geothermal exploration: United Nations Symp. on Development and Utilization of Geothermal Resources, Pisa, 22 Sept.-1 Oct. 1970, Proc.; Geothermics, spec. issue 2, v. 1, sec. 4, p. 32-57.

Bevington, P. R., 1969, Data reduction and error analysis for the physical sciences: New York, McGraw-Hill Book Company, $336 \mathrm{p}$.

Birnie, R. W., 1973, Infrared radiation thermometry of Guatemalan volcanoes: Bull. Volcanol., v. 37, no. 1, p. 1-36.

Björnsson, Helgi, 1974, Explanation of jökulhlaups from Grimsvötn, Vatnajökull, Iceland: Jökull, v. 24, p. 1-26.

Blackwell, D. D., 1978, Heat flow and energy loss in the western United States, chap. 8 of Smith, R. B., and Eaton, G. P., eds., Cenozoic tectonics and regional geophysics of the western Cordillera: Geol. Soc. America Mem. 152, p. 175-208.

Böðvarsson, Gunnar, 1961, Physical characteristics of natural heat resources in Iceland: Jökull, v. 11, p. 29-38.

Bonnet, G., 1960, Le rayonnement thermique du lac de laves du volcan Nyiragongo: Acad. Royale Sci. Outre-Mer Bull. Séances, v. 6 , no. 4, p. $709-714$.

Bortleson, G. C., Wilson, R. T., and Foxworthy, B. L., 1977, Water quality effects on Baker Lake of recent volcanic activity at Mount Baker, Washington: U.S. Geol. Survey Prof. Paper $1022-\mathrm{B}, 30 \mathrm{p}$.

Bowen, I. S., 1926, The ratio of heat losses by conduction and by evaporation from any water surface: Phys. Rev., v. 27, p. 779-787.

Brunt, David, 1939, Physical and dynamical meteorology, 2d ed.: Cambridge at the University Press, 428 p.

Budyko, M. H., 1956, Teplovoi balans zemnoi poverkhnosti [The heat balance of the earth's surface]: Hydrometeorological Press, Leningrad, 255 p. Translated by Nina A. Stepanova, U.S. Department of Commerce, Washington, D.C., 1958.

Burnham, C. W., Holloway, J. R., and Davis, N. F., 1969, Thermodynamic properties of water to $1000^{\circ} \mathrm{C}$ and 10,000 bars: Geol. Soc. America Spec. Paper no. 132, 96 p.

Coombs, H. A., 1939, Mt. Baker, a Cascade volcano: Geol. Soc. America Bull., v. 50, no. 10, p. 1493-1509.

Cummings, N. W., and Richardson, Burt, 1927, Evaporation from lakes: Phys. Rev., v. 30, p. 527-534.

Daniels, D. L., 1968, Integrated 8-14 $\mu$ emissivities of rocks from Mono Craters region, in Friedman, J. D., Thermal anomalies and geologic features of the Mono Lake area, California, as revealed by infrared imagery: U.S. Natl. Aeronautics and Space Adm. Tech. Letter 82, $84 \mathrm{p}$.

Davidson, George, 1885, Recent volcanic activity in the U.S.; eruptions of Mount Baker: Science, v. 6, no. 138, p. 262.

Dawson, G. B., 1964, The nature and assessment of heat flow from hydrothermal areas: New Zealand Jour. Geology and Geophysics, v. 7, no. 1, p. 155-171.

Decker, R. W., and Peck, D. L., 1967, Infrared radiation from Alae lava lake, Hawaii, in Geological Survey Research 1967: U.S. Geol. Survey Prof. Paper 575-D, p. D169-D175.

Delsemme, A.-H., 1960, Première contribution à l'étude du débit d'énergie du volcan Nyiragongo: Acad. Royale Sci. Outre-Mer Bull. Séances, v. 6, no. 4, p. 699-707.
Dickinson, D. J., 1973, Aerial infrared survey of Kawerau, Rotorua and Taupo urban area-1972: New Zealand Dept. Sci. and Indus. Research, Geophysics Dept. Rept. 89, 53 p.

Easterbrook, D. J., 1975, Mount Baker eruptions: Geology, v. 3, no. 12 , p. 679-682.

Easterbrook, D. J., and Rahm, D. A., 1970, Landforms of Washington-The geologic environment: Bellingham, Wash., Western Wash. State Coll., 156 p.

Eichelberger, J. C., Heiken, Grant, Widdicombe, R., Wright, D., Keady, C. J., and Cobb, D. D., 1976, New fumarolic activity on Mt. Baker-observations during April through July, 1975: Jour. Volcanology and Geothermal Research, v. 1, no. 1, p. 35-54.

Frank, David, Meier, M. F., and Swanson, D. A., 1977, Assessment of increased thermal activity at Mount Baker, Washington, March 1975-March 1976: U.S. Geol. Survey Prof. Paper 1022-A, 49 p.

Frank, David, and Post, Austin, 1976, Documentation of thermal changes by photographs of snow and ice features at Mount Baker, Washington, 1976 [abs.]: EOS (Am. Geophys. Union Trans.), v. 57 , no. 2 , p. 87.

Frank, David, Post, Austin, and Friedman, J. D., 1975, Recurrent geothermally induced debris avalanches on Boulder Glacier, Mount Baker, Washington: U.S. Geol. Survey Jour. Research, v. 3 , no. 1, p. $77-87$.

Fretwell, M. O., 1976, Water quality sampling and analyses activities related to Mount Baker's recent volcanic activity [abs.]: EOS (Am. Geophys. Union Trans.), v. 57, no. 2, p. 89.

Friedman, J. D., Preble, D. M., and Jakobsson, Sveinn, 1976, Geothermal flux through palagonitized tephra, Surtsey, Icelandthe Surtsey temperature data relay experiment via Landsat-1: U.S. Geol. Survey Jour. Research, v. 4, no. 6, p. 645-659.

Friedman, J. D., Williams, R. S., Jr., Pálmason, Guðmundur, and Miller, C. D., 1969, Infrared surveys in Iceland-preliminary report, in Geological Survey Research 1969: U.S. Geol. Survey Prof. Paper 650-C, p. C89-C105.

Friedman, J. D., Williams, R. S., Jr., Thorarinsson, Sigurður, 1970, Thermal emission from Hekla volcano, Iceland, before the eruption of May 5, 1970 [abs.]: Geol. Soc. America Abs. with Programs, v. 2 , no. 7, p. 555 .

Friedman, J. D., Williams, R. S., Jr., Thorarinsson, Sigurður, and Pálmason, Guơmundur, 1972, Infrared emission from Kverkfjöll subglacial volcanic and geothermal area, Iceland: Jökull, v. 22, p. 27-43.

Gebbie, H. A., Harding, W. R., Hilsum, C., Pryce, A. W., and Roberts, V., 1951, Atmospheric transmission in the 8-14 $\mu \mathrm{m}$ region: Royal Soc. [London] Proc., Series A, Mathematical and Physical Sciences, v. 206, p. 87-107.

Gibbs, George, 1874, Physical geography of the northwestern boundary of the United States: Am. Geog. Soc. Jour., v. 4, p. 298-415.

Gouffé, André, 1945, Corrections d'ouverture des corpsnoirs artificiels compte tenu des diffusions multiple internes: Rev. d'Optique Théorique et Instrumentale, v. 24, no. 1-3, p. 1-10.

Hyde, J. H., and Crandell, D. R., 1975, Origin and age of postglacial deposits and assessment of potential hazards from future eruptions of Mount Baker, Washington: U.S. Geol. Survey Open-File Rept. 75-286, $22 \mathrm{p}$.

Keenan, J. H., and Keyes, F. G., 1936, Thermodynamic properties of steam: New York, John Wiley and Sons, Inc., 89 p.

Kiver, E. P., and Steele, W. K., 1976, Volcano monitoring utilizing geothermal ice caves at Mounts Baker and Rainier, Washington [abs.]: EOS (Am. Geophys. Union Trans.), v. 57, no. 2, p. 89.

McClatchey, R. A., Fenn, R. W., Selby, J. E. A., Volz, F. E., and Garing, J. S., 1972, Optical properties of the atmosphere, 3d ed.: U.S. Air Force Cambridge Research Labs., AFCRL-72-0497, Environmental Research Papers, no. 411, 108 p. 
McLane, J. E., Finkelman, R. B., and Larson R. R., 1976a, Examination of sulfur-pyrite spherules from Mt. Baker, Washington: Mineralog. Rec., July-Aug., 1976, p. 170-171.

1976b, Mineralogical examination of particulate matter from the fumaroles of Sherman Crater, Mt. Baker, Washington [abs.]: EOS (Am. Geophys. Union Trans.), v. 57, no. 2, p. 89.

Malone, S. D., 1976a, Deformation of Mount Baker volcano by hydrothermal heating [abs.]: EOS (Am. Geophys. Union Trans.), v. 57 , no. 12 , p. 1016 .

1976b, Seismic and gravity observations on Mount Baker volcano [abs.]: $\operatorname{EOS}$ (Am. Geophys. Union Trans.), v. 57, no. 2, p. 88.

1979, Gravity changes accompanying increased heat emission at Mount Baker, Washington: Jour. Volcanology and Geothermal Research, v. 6, nos. 3 and 4, p. 241-256.

Malone, S. D., and Frank, David, 1975, Increased heat emission from Mount Baker, Washington: EOS (Am. Geophys. Union Trans.), v. 56 , no. 10 , p. $679-685$.

Misch, Peter, 1966, Tectonic evolution of the Northern Cascades of Washington State-a west-cordilleran case history, in A symposium on the tectonic history and mineral deposits of the western cordillera, Vancouver, B.C., 1964: Canadian Inst. Mining and Metallurgy Spec. Vol. 8, p. 101-148.

Nitsan, Uzi, 1976, The effect of increased geothermal heat flux on the flow of Mt. Baker glaciers [abs.]: EOS (Am. Geophys. Union Trans.), v. 57, no. 2 , p. 89.

Nolf, Bruce, 1976, Tilt-bar stations on Mt. Baker, Washington [abs.]: EOS (Am. Geophys. Union Trans.), v. 57, no. 2, p. 88.

Pálmason, Guðmundur, Friedman, J. D., Williams, R. S., Jr., Jónsson, Jón, and Saemundsson, Kristján, 1970, Aerial infrared surveys of Reykjanes and Torfajökull thermal areas, Iceland: United Nations Symp. on Development and Utilization of Geothermal Resources, Pisa, 22 Sept.-1 Oct. 1970, Proc.; Geothermics, spec. issue 2, v. 2, pt. 1, p. 399-412.

Perry, J. H., Perry, R. H., Chilton, C. H., and Kirkpatrick, S. D., 1969, Chemical engineers' handbook, 4th ed.: New York, McGraw-Hill.

Pioneer-Democrat (newspaper), 1859 [Untitled]: Olympia, Washington Territory, Pioneer-Democrat, v. 8, no. 1, Nov. 25, 1859.

Polak, B. G., 1967, An energy appraisal of volcanic and hydrothermal phenomena (on the example of Kamchatka): Bull. Volcanologique, v. 30, p. 129-138.

Preble, D. M., Friedman, J. D., and Frank, David, 1977, Electronic thermal sensor and Landsat Data Collection Platform technology: U.S. Geol. Survey Open-File Rept. 77-87, 64 p. (Also available from U.S. Natl. Tech. Inf. Service, Springfield, VA 22161, as rept. N78-23500/LLL.)

Radke, L. F., Hobbs, T. V., and Stith, J. L., 1976, Airborne measurements of gases and aerosols from volcanic vents on Mt. Baker: Geophys. Research Letters, v. 3, no. 2, p. 93-96.

Robertson, E. I., and Dawson, G. B., 1964, Geothermal heat flow through the soil at Wairakei: New Zealand Jour. Geology and Geophysics, v. 7, no. 1, p. 134-143.

Robin, G. de Q., 1976, Is the basal ice of a temperate glacier at the pressure melting point?: Jour. Glaciology, v. 16, no. 74, p. 183-195.
Robson, G. R., and Willmore, P. L., 1955, Some heat measurements in West Indian soufrières: Bull. Volcanologique, v. 17, p. 13-39.

Rosenfeld, C. L., 1976, Operational aerial surveillance of the Sherman Crater area, Mt. Baker, Washington [abs.]: EOS (Am. Geophys. Union Trans.), v. 57, no. 3, p. 87.

— 1977, Summary of thermal infrared observations, in Frank, David, Meier, M. F., and Swanson, D. A., Assessment of increased thermal activity at Mount Baker, Washington, March 1975-March 1976: U.S. Geol. Survey Prof. Paper 1022-A, p. A12-A14.

Rusk, Claude E., 1924, Tales of a western mountaineer: Boston, Mass., Houghton-Mifflin Co., 309 p.

Sato, Motoaki, Malone, S. D., Moxham, R. M., and McLane, J. E., 1976, Monitoring of fumarolic gas at Sherman Crater, Mt. Baker, Washington [abs.]: EOS (Am. Geophys. Union Trans.), v. 57 , no. 2 , p. 88.

Saunders, P. M., 1970, Corrections for airborne radiation thermometry: Jour. Geophys. Res., v. 75, no. 36, p. 7596-7601.

Sekioka, Mitsuru, and Yuhara, Kozo, 1974, Heat flux estimation in geothermal areas based on the heat balance of the ground surface: Jour. Geophys. Res., v. 79, no. 14, p. 2053-2058.

Sutton, O. G., 1953, Micrometeorology: New York, McGraw-Hill, 333 p.

Swanson, D. A., 1972, Magma supply rate at Kilauea volcano, 1952-1971: Science, v. 175, p. 169-170.

Swanson, D. A., Wright, T. L., and Helz, R. T., 1975, Linear vent systems and estimated rates of magma production and eruption for the Yakima basalt of the Columbia Plateau: Am. Jour. Sci., v. 275 , no. 8 , p. $877-905$.

Theakstone, W. H., 1967, Basal sliding and movement near the margin of the glacier $\emptyset$ sterdalsisen, Norway: Jour. Glaciology, v. 6, no. 48 , p. $805-816$.

Vicker, R. S., and Lyon, R. J. P., 1967, Infrared sensing from spacecraft-A geologic interpretation, in Heller, G. B., ed., Thermophysics of spacecraft and planetary bodies: New York, Academic Press, p. 585-607.

Vivian, Robert, and Bocquet, Gerard, 1973, Subglacial cavitation phenomena under the Glacier d'Argentière, Mont Blanc, France: Jour. Glaciology, v. 12 , no. 66 , p. 439-451.

Washburn, E. W., 1929, International critical tables of numerical data, physics, chemistry and technology, volume 5: New York, Published for the National Research Council by McGraw-Hill Book Co., 470 p.

Watson, Kenneth, 1971, A computer program of thermal modeling for interpretation of infrared images: U.S. Geol. Survey Rept. USGS-GD-71-023, 33 p.; available only from U.S Dept. Commerce Natl. Tech. Inf. Service, Springfield, VA 22161, as Rept. PB-03578.

1975, Geologic applications of thermal infrared images: IEEE Proc., v. 63, no. 1, p. 128-137.

Weast, R. C., ed., 1970, Handbook of chemistry and physics, 51st ed.: Cleveland, Chemical Rubber Co.

Yokoyama, Izumi, 1972, Heat and mass transfer through volcanoes: Rev. Italiana Geofisica, v. 21, p. 165-169. 



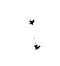


